OPEN ACCESS

Edited by:

Yan Li,

Auckland University of Technology,

New Zealand

Reviewed by:

John Patrick Gleeson,

Merck and Co., Inc., United States

Ikumi Tamai,

Kanazawa University, Japan

*Correspondence:

Zheng Cai

caizheng2002@sina.com

Menghua Liu

liumenghua@smu.edu.cn

Specialty section:

This article was submitted to

Drug Metabolism and Transport,

a section of the journal

Frontiers in Pharmacology

Received: 23 July 2021 Accepted: 27 October 2021 Published: 29 November 2021

Citation: Zou W, Shi B, Zeng T, Zhang $Y$, Huang B, Ouyang B, Cai Z and Liu M (2021) Drug Transporters in the Kidney: Perspectives on Species Differences, Disease Status, and

Molecular Docking.

Front. Pharmacol. 12:746208. doi: 10.3389/fphar.2021.746208

\section{Drug Transporters in the Kidney: Perspectives on Species Differences, Disease Status, and Molecular Docking}

\author{
Wei Zou ${ }^{1}$, Birui Shi ${ }^{2}$, Ting Zeng ${ }^{1}$, Yan Zhang ${ }^{2}$, Baolin Huang ${ }^{2}$, Bo Ouyang ${ }^{1}$, Zheng Cai ${ }^{2,3 *}$ and \\ Menghua Liu ${ }^{2,3 *}$ \\ ${ }^{1}$ Changsha Research and Development Center on Obstetric and Gynecologic Traditional Chinese Medicine Preparation, NHC \\ Key Laboratory of Birth Defects Research, Prevention and Treatment, Hunan Provincial Maternal and Child Health Care Hospital, \\ Changsha, China, ${ }^{2}$ Biopharmaceutics, NMPA Key Laboratory for Research and Evaluation of Drug Metabolism, School of \\ Pharmaceutical Sciences, Southern Medical University, Guangzhou, China, ${ }^{3}$ TCM-Integrated Hospital, Southern Medical \\ University, Guangzhou, China
}

The kidneys are a pair of important organs that excretes endogenous waste and exogenous biological agents from the body. Numerous transporters are involved in the excretion process. The levels of these transporters could affect the pharmacokinetics of many drugs, such as organic anion drugs, organic cationic drugs, and peptide drugs. Eleven drug transporters in the kidney (OAT1, OAT3, OATP4C1, OCT2, MDR1, BCRP, MATE1, MATE2-K, OAT4, MRP2, and MRP4) have become necessary research items in the development of innovative drugs. However, the levels of these transporters vary between different species, sex-genders, ages, and disease statuses, which may lead to different pharmacokinetics of drugs. Here, we review the differences of the important transports in the mentioned conditions, in order to help clinicians to improve clinical prescriptions for patients. To predict drug-drug interactions (DDIs) caused by renal drug transporters, the molecular docking method is used for rapid screening of substrates or inhibitors of the drug transporters. Here, we review a large number of natural products that represent potential substrates and/or inhibitors of transporters by the molecular docking method.

Keywords: renal drug transporters, species, sex-genders, ages, molecular docking, disease status

\section{INTRODUCTION}

The kidneys are the main excretory organs of the body, which play key roles in excretion of metabolites, acid-base balance, and homeostasis of the body system. The secretion and reabsorption effects of renal tubules are mainly mediated by transporters. It is not only an effective mechanism for the reabsorption of nutrients, such as glucose and amino acids, but also an effective way to remove endogenous waste and exogenous biological agents. Up to now, renal excretions of many drugs (including organic anion drugs, organic cationic drugs, and peptide drugs) are mediated by drug transporters concentrated on proximal renal tubules (Ivanyuk et al., 2017). On the one hand, uptake transporters, such as organic anion transporters (OATs) and organic cationic transporters (OCTs), on the basolateral membrane of renal tubular epithelial cells take up drugs from the blood side into cells. On the other hand, efflux transporters, such as 
TABLE 1 | The main drug transporters on the proximal tubular cells.

\begin{tabular}{|c|c|c|c|c|}
\hline Protein & Full name & Location & Gene in human & UniProt ID \\
\hline OAT1 & Organic anion transporter 1 & Basolateral membrane & SLC22A6 & Q4U2R8 \\
\hline OAT3 & Organic anion transporter 3 & Basolateral membrane & SLC22A8 & Q8TCC7 \\
\hline OATP4C1 & Organic anion transporter polypeptide 4C1 & Basolateral membrane & SLCO4C1 & Q6ZQN7 \\
\hline Ост2 & Organic cation transporter & Basolateral membrane & SLC22A2 & 015244 \\
\hline MDR1 & Multidrug resistance protein 1 & Apical membrane & $A B C B 1$ & P08183 \\
\hline BCRP & Breast cancer resistance protein & Apical membrane & ABCG2 & Q9UNQ0 \\
\hline MATE1 & Multidrug and toxin extrusion protein 1 & Apical membrane & SLC47A1 & Q96FL8 \\
\hline MATE2-K & Multidrug and toxin extrusion protein $2-\mathrm{k}$ & Apical membrane & SLC47A2 & Q86VL8 \\
\hline OAT4 & Organic anion transporter 4 & Apical membrane & SLC22A11 & Q9NSA0 \\
\hline MRP2 & Multidrug resistance protein 2 & Apical membrane & $A B C C 2$ & Q92887 \\
\hline MRP4 & Multidrug resistance protein 4 & Apical membrane & $A B C C 4$ & 015439 \\
\hline
\end{tabular}

UniProt: https://www.uniprot.org/

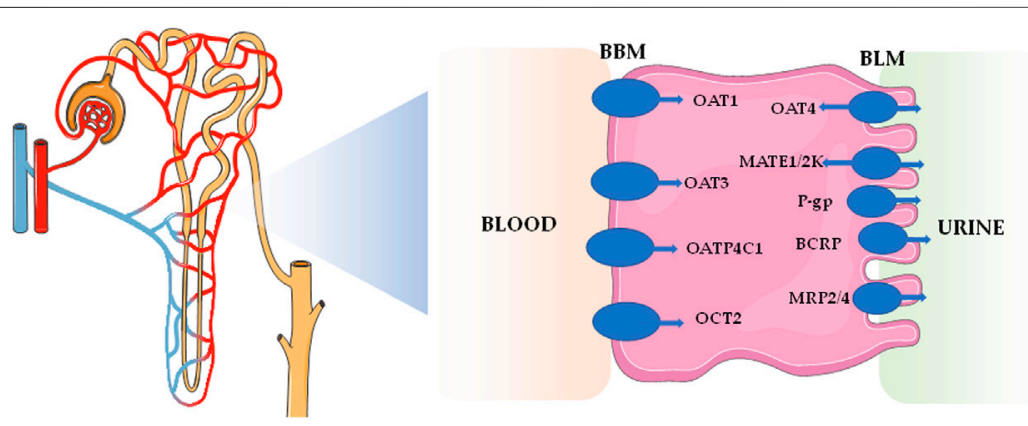

FIGURE 1 | Distribution of the major transporters located in kidney.

multidrug and toxin extrusion proteins (MATEs) and multidrug resistance proteins (MRPs), located on the brush edge of renal tubular epithelial cells discharge intracellular drugs into the lumen for secretion and excretion (Gozalpour and Fenner, 2018). The study on drug transporters has become one of the main trends in the field of pharmacokinetics. Impacts on 11 drug transporters in the kidneys, including OAT1, OAT3, organic anion transporter polypeptide $4 \mathrm{C} 1$ (OATP4C1), organic cation transporter (OCT2), multidrug resistance protein 1 [MDR1, namely p-glycoproteins (P-gp)], breast cancer resistance protein (BCRP), MATE1, MATE2-K, OAT4, multidrug resistanceassociated protein 2 (MRP2), and MRP4, have become necessary research items in the development of innovative drugs (Food and Drug Administration, 2020). These drug transporters are mainly distributed on the basolateral membrane and apical membrane of renal proximal tubular cells, which are shown in Table $\mathbf{1}$ and Figure $\mathbf{1}$.

At present, pharmacokinetic data in drug instructions are primarily derived from healthy subjects, and most pharmacokinetic experiments are performed in healthy adult animals to evaluate drug safety and in vivo processes (absorption, distribution, metabolism, and excretion). However, two issues require attentions: 1) Which characteristics of the animal model (such as species, age, sex-gender, and disease status) can best reflect pharmacokinetic behaviour in humans? 2) Does the pharmacokinetic data from healthy subjects (human and/or animal) appropriately reflect the disease status? Extensive literature in recent decades has shown that the changes of drug transports in the disease status will lead to the changes of the drug pharmacokinetic behaviour, which directly affect the performance of drug efficacy or produce toxicities and side effects (Yang and Han, 2019). Therefore, it is very important to understand the changes of transporters in the disease status for optimizing clinical drug administration. In addition, patients often take multiple drugs simultaneously in clinic, and then drugs may cause drug-drug interactions (DDIs), which result in serious adverse reactions or an altered treatment outcome. A statistical study of hospitalized elderly patients has revealed that the prevalence of DDIs ranged from 8.34 to $100 \%$ (de Oliveira et al., 2021). Drug transporter variation is one of the mechanisms of DDIs, as the drugs may be substrates or mediators of the drug transporters. At present, computer-based drug design is widely used in drug development to simulate the chemical structural interactions between biomacromolecules and drugs, and hence, this technique has been used in transporter studies to quickly predict DDIs in clinic (Marques et al., 2019).

In this review, we mainly discuss the renal transporter expression differences on species, sex-gender, and age, as well as the changes of drug transporters under disease statuses. Furthermore, the molecular docking technology applied on renal drug transporters was reviewed, which could facilitate 
TABLE 2 | The expressions of main drug transporters in different species and sex-genders.

\begin{tabular}{|c|c|c|c|c|c|c|c|c|c|c|c|c|c|c|}
\hline \multirow[t]{2}{*}{ Species } & \multirow[t]{2}{*}{ Method } & \multirow[t]{2}{*}{ Units } & \multicolumn{11}{|c|}{ Transporters } & \multirow[t]{2}{*}{ Reference } \\
\hline & & & OAT1 & ОАТ3 & OATP4C1 & Ост2 & MDR1 & BCRP & MATE1 & $\begin{array}{l}\text { MATE2- } \\
\mathrm{K}\end{array}$ & OAT4 & MRP2 & MRP4 & \\
\hline \multirow[t]{4}{*}{ Human } & $\begin{array}{l}\text { LC- } \\
\text { MS/MS }\end{array}$ & pmol g ${ }^{-1}$ & $\begin{array}{c}107.7 \pm \\
56.83\end{array}$ & $78.5 \pm 37.38$ & $0.3 \pm 0.03$ & $\begin{array}{c}164.2 \pm \\
53.27\end{array}$ & $\begin{array}{l}42.3 \pm \\
16.16\end{array}$ & BLQ & $\begin{array}{c}105.6 \pm \\
47.52\end{array}$ & - & $\begin{array}{c}10.6 \pm \\
5.64\end{array}$ & $\begin{array}{l}30.1 \pm \\
16.52\end{array}$ & $\begin{array}{l}19.5 \pm \\
20.58\end{array}$ & Basit et al. (2019) \\
\hline & $\begin{array}{l}\text { LC- } \\
\text { MS/MS }\end{array}$ & pmol mg ${ }^{-1}$ & - & - & - & - & $\begin{array}{c}3.89 \pm \\
1.30\end{array}$ & - & - & - & - & $\begin{array}{c}0.10 \pm \\
0.08\end{array}$ & $\begin{array}{c}0.15 \pm \\
0.08\end{array}$ & Fallon et al. (2016) \\
\hline & $\begin{array}{l}\text { LC- } \\
\text { MS/MS }\end{array}$ & $\begin{array}{l}\text { fmol } \mu g^{-1} \text { of } \\
\text { microsomes }\end{array}$ & $\begin{array}{c}5.31 \pm \\
0.07\end{array}$ & $9.68 \pm 0.18$ & BLQ & $5.12 \pm 0.07$ & $\begin{array}{l}4.45 \pm \\
0.07\end{array}$ & $\begin{array}{c}0.66 \pm \\
0.02\end{array}$ & $10.8 \pm 0.1$ & $\begin{array}{l}2.19 \pm \\
0.05\end{array}$ & $\begin{array}{c}1.56 \pm \\
0.03\end{array}$ & $\begin{array}{l}1.04 \pm \\
0.02\end{array}$ & $\begin{array}{c}1.49 \pm \\
0.04\end{array}$ & $\begin{array}{l}\text { Nakamura et al. } \\
(2016)\end{array}$ \\
\hline & $\begin{array}{l}\text { LC- } \\
\text { MS/MS }\end{array}$ & pmol mg ${ }^{-1}$ & - & - & - & - & $\begin{array}{c}3.63 \pm \\
1.14\end{array}$ & $\begin{array}{l}0.09 \pm \\
0.02\end{array}$ & - & - & - & $\begin{array}{l}0.48 \pm \\
0.27\end{array}$ & - & $\begin{array}{l}\text { Al-Majdoub et al. } \\
\text { (2020) }\end{array}$ \\
\hline sex & $\begin{array}{l}\text { LC- } \\
\text { MS/MS }\end{array}$ & - & $\leftrightarrow$ & $\leftrightarrow$ & ND & $\leftrightarrow$ & $\leftrightarrow$ & $B L Q$ & $\leftrightarrow$ & - & $\leftrightarrow$ & $\leftrightarrow$ & $\leftrightarrow$ & Basit et al. (2019) \\
\hline \multirow[t]{2}{*}{ Monkey } & $\begin{array}{l}\text { LC- } \\
\text { MS/MS }\end{array}$ & $\mathrm{pmol} \mathrm{g}^{-1}$ & $\begin{array}{c}242.5 \pm \\
62.69\end{array}$ & $124.7 \pm 32.57$ & $0.7 \pm 0.28$ & $\begin{array}{l}464.8 \pm \\
147.18\end{array}$ & $52 \pm 9.44$ & BLQ & $\begin{array}{c}161.2 \pm \\
56.23\end{array}$ & - & $\begin{array}{c}17.5 \pm \\
6.28\end{array}$ & $\begin{array}{c}56 \pm \\
13.99\end{array}$ & $\begin{array}{c}71.3 \pm \\
18.73\end{array}$ & Basit et al. (2019) \\
\hline & $\begin{array}{l}\text { LC- } \\
\text { MS/MS }\end{array}$ & $\mathrm{pmol} \mathrm{mg}^{-1}$ & - & - & - & - & $\begin{array}{c}3.05 \pm \\
2.11\end{array}$ & $\begin{array}{c}0.42 \pm \\
0.36\end{array}$ & - & - & - & $\begin{array}{c}0.52 \pm \\
0.46\end{array}$ & - & Fallon et al. (2016) \\
\hline sex & $\begin{array}{l}\text { LC- } \\
\text { MS/MS }\end{array}$ & & $\leftrightarrow$ & $\leftrightarrow$ & $\leftrightarrow$ & $\leftrightarrow$ & $\leftrightarrow$ & BLQ & $\leftrightarrow$ & - & $\leftrightarrow$ & $\leftrightarrow$ & $\leftrightarrow$ & Basit et al. (2019) \\
\hline \multirow[t]{2}{*}{ Dog } & $\begin{array}{l}\text { LC- } \\
\text { MS/MS }\end{array}$ & pmol g ${ }^{-1}$ & $\begin{array}{l}75.4 \pm \\
43.07\end{array}$ & NC & NC & NC & $\begin{array}{c}32.1 \pm \\
9.34\end{array}$ & NC & NC & - & NC & NC & NC & Basit et al. (2019) \\
\hline & $\begin{array}{l}\text { LC- } \\
\text { MS/MS }\end{array}$ & $\mathrm{pmol} \mathrm{mg}{ }^{-1}$ & - & - & - & - & 1.07 & 0.15 & - & - & - & 0.55 & - & Fallon et al. (2016) \\
\hline sex & $\begin{array}{l}\text { LC- } \\
\text { MS/MS }\end{array}$ & - & $\leftrightarrow$ & NC & NC & NC & $\mathrm{F}>\mathrm{M}^{\star} 1.4$ & NC & NC & - & NC & NC & NC & Basit et al. (2019) \\
\hline \multirow[t]{3}{*}{ Rat } & $\begin{array}{l}\text { LC- } \\
\text { MS/MS }\end{array}$ & $\mathrm{pmol} \mathrm{g}^{-1}$ & $\begin{array}{l}308.8 \pm \\
79.24\end{array}$ & NC & NC & $\begin{array}{l}253.5 \pm \\
70.92\end{array}$ & $\begin{array}{c}39.3 \pm \\
11.76\end{array}$ & $1.3 \pm 0.4$ & NC & - & NC & NC & $\begin{array}{c}37.5 \pm \\
7.51\end{array}$ & Basit et al. (2019) \\
\hline & $\begin{array}{l}\text { LC- } \\
\text { MS/MS }\end{array}$ & pmol mg ${ }^{-1}$ & - & - & - & - & $\begin{array}{c}1.74 \pm \\
1.09\end{array}$ & $\begin{array}{c}4.50 \pm \\
2.88\end{array}$ & - & - & - & $\begin{array}{c}0.27 \pm \\
0.21\end{array}$ & - & Fallon et al. (2016) \\
\hline & $\begin{array}{l}\text { LC- } \\
\text { MS/MS }\end{array}$ & $\mathrm{fmol} \mathrm{mg^{-1 }}$ & $10.5 \pm 1.1$ & $6.71 \pm 1.03$ & - & - & $\begin{array}{c}0.682 \pm \\
0.103\end{array}$ & $\begin{array}{c}15.9 \pm \\
1.5\end{array}$ & $\begin{array}{c}2.04 \pm \\
0.18\end{array}$ & - & - & - & $\begin{array}{l}0.539 \pm \\
0.090\end{array}$ & - \\
\hline sex & - & - & $M>F^{*} 1.3$ & NC & NC & $M>F^{*} 1.4$ & $M>F^{*} 1.6$ & $\begin{array}{c}M \\
>F^{*} 1.6\end{array}$ & NC & - & NC & $\mathrm{NC}$ & $\leftrightarrow$ & Basit et al. (2019) \\
\hline Mouse & $\begin{array}{l}\text { LC- } \\
\text { MS/MS }\end{array}$ & pmol g ${ }^{-1}$ & $\begin{array}{c}156.2 \pm \\
92.06\end{array}$ & NC & NC & $\begin{array}{r}429.1 \pm \\
134.67\end{array}$ & $\begin{array}{c}15.5 \pm \\
5.99\end{array}$ & $\begin{array}{c}3.1 \pm \\
0.88\end{array}$ & NC & - & NC & NC & $8.6 \pm 3.94$ & Basit et al. (2019) \\
\hline \multirow[t]{3}{*}{ sex } & $\begin{array}{l}\text { LC- } \\
\text { MS/MS }\end{array}$ & - & $M>F^{\star} 3.2$ & NC & NC & $M>F^{\star} 1.6$ & $F>M^{\star} 2.0$ & $\leftrightarrow$ & NC & - & NC & NC & $F>M^{\star} 2.4$ & Basit et al. (2019) \\
\hline & qPCR & $\mathrm{RLU} / 10 \mu \mathrm{g}$ & $M>F$ & $\begin{array}{c}\leftrightarrow \text { in C57BL/6 } 6 \\
\text { mice }\end{array}$ & - & - & - & - & - & - & - & - & - & $\begin{array}{l}\text { Buist and } \\
\text { Klaassen, (2004) }\end{array}$ \\
\hline & - & - & - & $\begin{array}{c}\mathrm{M}<\mathrm{F} \text { in } 129 \mathrm{~J} \\
\text { mice }\end{array}$ & - & - & - & - & - & - & - & - & - & - \\
\hline
\end{tabular}

NC: no conserved peptide; $\leftrightarrow:$ No significant difference; ND: sex difference was not determined; BLQ: below limit of quantification; /: not mentioned. 
the prediction of DDIs for improving the safety and effectiveness of drugs in clinic.

\section{THE EXPRESSIONS OF DRUG TRANSPORTERS IN KIDNEY ACROSS SPECIES, SEX-GENDER, AND AGE \\ Species}

Preclinical trials are essential for evaluating drug safety, efficacy, toxicity, and pharmacokinetics. It is necessary to understand the difference between humans and animals at the levels of drug transporters. Along with quantitative real time-polymerase chain reaction (qPCR) and Western blot, the highly sensitive liquid chromatography tandem-mass spectrometry (LC-MS/MS) has become one of the most effective methods in the quantitative detection of drug transporters (Fallon et al., 2016; Nakamura et al., 2016; Basit et al., 2019). Table 2 has shown the species differences of renal drug transporters found in past decades. Basit et al. (2019) showed that the abundances of OAT1, OCT2, and MATE1 in human renal tissue were higher than the other eight drug transporters. The levels of OAT1, OAT3, OATP4C1, OCT2, MDR1, MATE1, OAT4, MRP2, and MRP4 in monkey were from 1.6-fold to 3.7-fold higher than that in human. OATP4C1, MATE1, MATE2-K, OAT4C1, and MRP2 in rat and mouse, as well as OATP4C1, OCT2, MATE1, MATE2-K, OAT4C1, MRP2, and MRP4 in dog, were not detected as no conserved peptide available (Basit et al., 2019). Fallon et al. (2016) have revealed three renal efflux transporters in human, monkey, dog, and rat. The concentrations of MDR1 and MRP2 were similar in human and monkey, but higher than that in rat. However, the BCRP level was the highest in rat $\left(4.5 \mathrm{pmol} \mathrm{mg}^{-1}\right.$ protein), which is 50 -fold than that in human $\left(0.09 \mathrm{pmol} \mathrm{mg}^{-1}\right.$ protein). In another study, 11 transporters were detected in the pooled microsomal fraction of human kidney (Nakamura et al., 2016). All transporters, except for OATP4C1, have sensitive responses when detection. The content of BCRP (3.6-4.5 $\mathrm{pmol} \mathrm{mg}^{-1}$ ) was similar as the other reports (Fallon et al., 2016; Nakamura et al., 2016; Al-Majdoub et al., 2020). Many exogenous substances show species differences in excretion. Taking per- and polyfluoroalkyl substances (PFAS) as an example, a longer serum half-life in human $\left(\mathrm{t}_{1 / 2}\right)$, compared to that in animal species, is potentially due to the difference in excretion which was mediated by renal tubular OATs and OATPs (Ducatman et al., 2021). Therefore, the differences on cross-species kidney transporters should be carefully considered in drug preclinical-to-clinical stage.

\section{Sex-Gender and Pregnancy}

As an important factor, sex-gender should attract a full attention in the context of drug development and clinical use. Between 1995 and 2000, 11 out of 300 new drug applications recorded by the Food and Drug Administration (FDA) showed $>40 \%$ sexgender differences in pharmacokinetics (Anderson, 2005). Taking methotrexate as an example, after 1,277 osteosarcoma patients were treated with a high dose of methotrexate, the incidence of delayed excretion in female patients was about $1.75 \%$, which was significantly higher than that in male patients (0.37\%) (Zhang et al., 2016). It has been reported that OAT1, OAT3, OATP4C1, OCT2, MDR1, MATE1, OAT4, MRP2, and MRP4 in the kidney show no sex-gender differences in healthy monkeys. However, significant sexgender differences of OAT1, OCT2, MDR1, BCRP, and MRP4 are observed in rats and/or mice with different trends (Buist and Klaassen, 2004; Basit et al., 2019). For example, the abundance of MDR1 was 1.6-fold greater in male rats than that in the females, whereas its expression was twice as high in female mice compared with that in the males. It has been shown that OATP4C1, BCRP, and MATE2-K levels exhibited sex-based differences between healthy men and women (Basit et al., 2019). Due to sex-gender differences in transporter expression, full consideration should be given to pharmacokinetic, safety, efficacy, and toxicity studies of drug to allow better interpretation of clinical data. For example, $2 \mathrm{~h}$ after oral administration of metformin at a dose of $500 \mathrm{mg} / \mathrm{kg}$, the cumulative urinary excretion and renal tissue-to-plasma concentration ratio in female rats $(26,689 \pm 1,266 \mu \mathrm{g}$ and $2.96 \pm 0.47 \mathrm{ml} / \mathrm{g}$, respectively) were markedly lower than that in male rats $(32,949 \pm 1,384 \mu \mathrm{g}$ and $4.20 \pm 0.31 \mathrm{ml} / \mathrm{g}$, respectively), which are potentially explained by gender-related differences on renal OCT2 expression, as the metformin is the substrate of OCT2 (Ma et al., 2016). Pregnancy is an especial physiological status for women. Lu et al. have proved no significant differences among OAT1/3, OCT2, MRP2, and MATE1 mRNA expressions in the kidneys between pregnant and non-pregnant rats (Lu et al., 2020).

\section{Age}

Age affects the transcription and translation of drug transporters. Joseph et al. (2015) have determined 30 drug transporters in two groups of human kidneys (age $<50$ years and $\geq 50$ years). Among them, the mRNA expression of the OCT2 in the $<50$ years group was greater than that in the $\geq 50$ years group (Joseph et al., 2015). The nephrotoxicity of cisplatin exhibits an age dependence in human. Wen et al. (2015) had analyzed 182 cisplatin-treated patients to illuminate the influence of nongenetic factors on cisplatin-induced nephrotoxicity, and age ( $\geq 50$ years) is closely associated with the decline of renal function with an odds ratio (OR) of 11.771. This might be due to the fact that the MATE1, which excretes cisplatin into urine, was significantly decreased with the increasing age ( $\geq 50$ years), resulting in the specific accumulation of cisplatin in renal cells. Although it is difficult to investigate the changes of drug transporters in the human kidney throughout life, an age-related study on OAT1, OAT3, OATP4C1, OCT2, MDR1, BCRP, MATE1, MATE2-K, MRP2, and MRP4 mRNA expressions was performed in male rat kidneys with qPCR and Western blot methods (Xu et al., 2017). In this preclinical study, all the detected drug transporters showed different increasing trends. As shown in Figure 2, the mRNA expressions of OAT1, OATP4C1, OCT2, BCRP, MATE1, and MATE2-K reached the peaks at the 180 th day and subsequently declined. Compared with the mRNA expressions at the -2nd day and/or the 1st day, the expressions at the peak were 35-fold, 35fold, 470-fold, 18-fold, 18-fold, and 37-fold greater for six drug transporters, respectively. The mRNA expressions of OAT3 and MRP2 reached the peak at the 850th day. For OAT3, the mRNA 


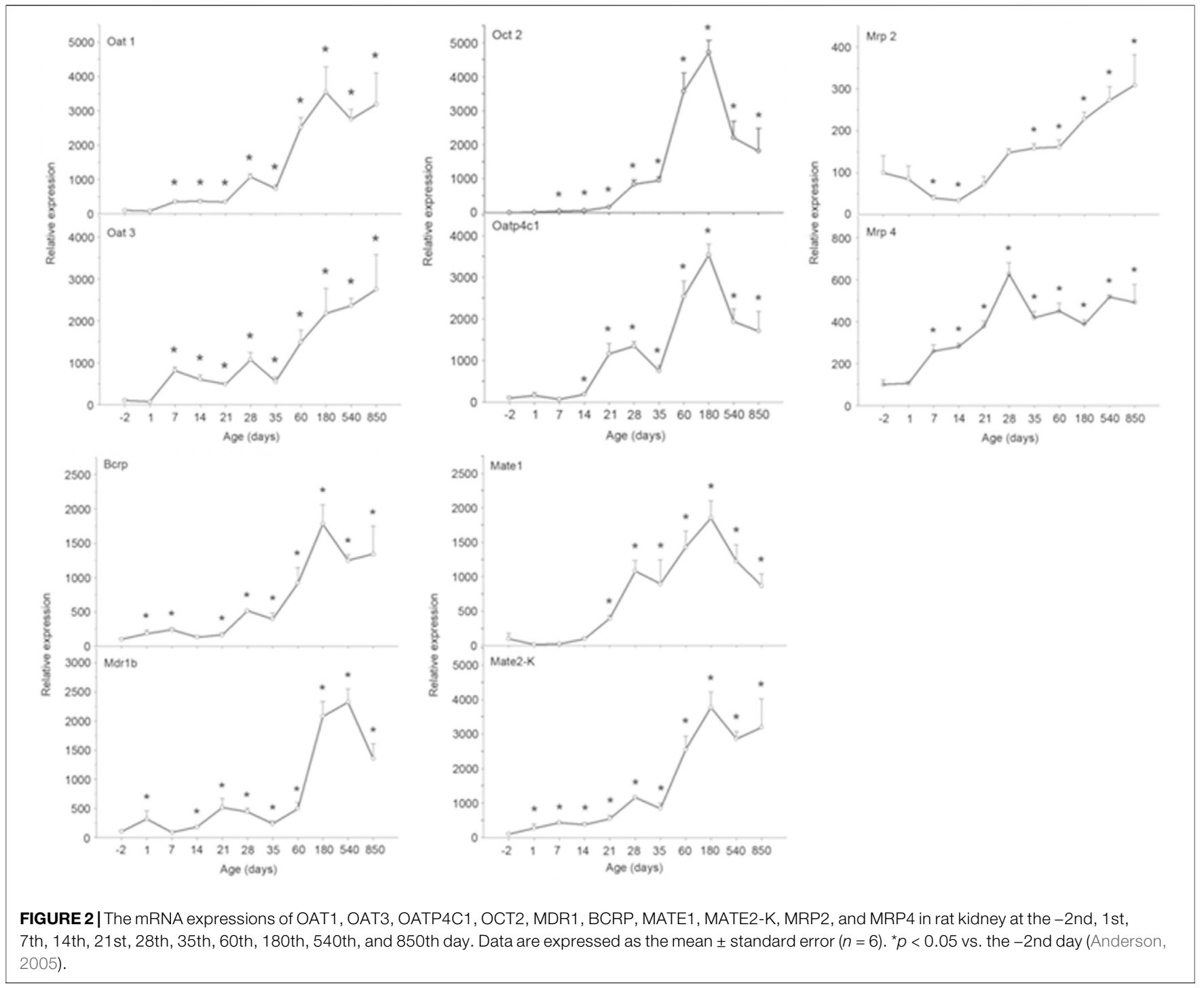

expression at the 180th day was 22 -fold greater than that at the 1 st day, while it was 3 -fold greater at the 850th day than that at the -2nd day for MRP2. Interestingly, the mRNA expression of MRP2 was reduced almost $50 \%$ at the 14 th and the 21 st day compared with the -2nd day. The mRNA expression of MRP4 reached peak at the 28th day, and it was 6-fold higher in comparison with that at the -2nd day. Ren et al. (2015) used both young rats (aged 3 months) and old rats (aged 12 months) to illuminate age-related excretion of metformin. The values of $\mathrm{t}_{1 / 2}$, accumulation in urine, and total clearance $\left(\mathrm{CL}_{\text {tot }}\right)(1.717 \pm 0.30 \mathrm{~h}, 6,088.402 \pm 931.55 \mu \mathrm{g}$, and $93.414 \pm 11.47 \%$, respectively) in young rats were significantly different from those indexes in old rats $(2.002 \pm$ $0.51 \mathrm{~h}, 4,287.087 \pm 458.08 \mu \mathrm{g}$, and $57.161 \pm 18.59 \%$, respectively). A significant age-related decrease of OCT2 is probably responsible for renal excretion of metformin (Ren et al., 2015). Although the lives of experimental animals are much shorter than that of human, we still clarity that the drug transporter undergoes a dynamic change throughout the life. Thus, drug transporters should receive close attentions at fetal, neonatal, mature, and old ages during drug development and clinical use (Andreollo et al., 2012; Sengupta, 2013; Gleeson et al., 2021; Vinarov et al., 2021).

\section{EFFECT OF DISEASES ON TRANSPORTER EXPRESSION AND FUNCTION Effect of Renal-Related Diseases on Drug Transporters in Kidney}

Kidney diseases, such as chronic kidney disease (CKD), acute kidney injury (AKI), and renal failure, can change the excretion rate of endogenous and/or exogenous substances, mainly due to a decrease in the glomerular filtration rate and the changes in drug transporters and metabolic enzyme activities. Levels of renal drug transporters are crucial for drug excretion, as drugs were mainly excreted through these transporters. As shown in Table 3, the mRNA and/or protein levels of drug transporters in renal-related disease models were summarized. 


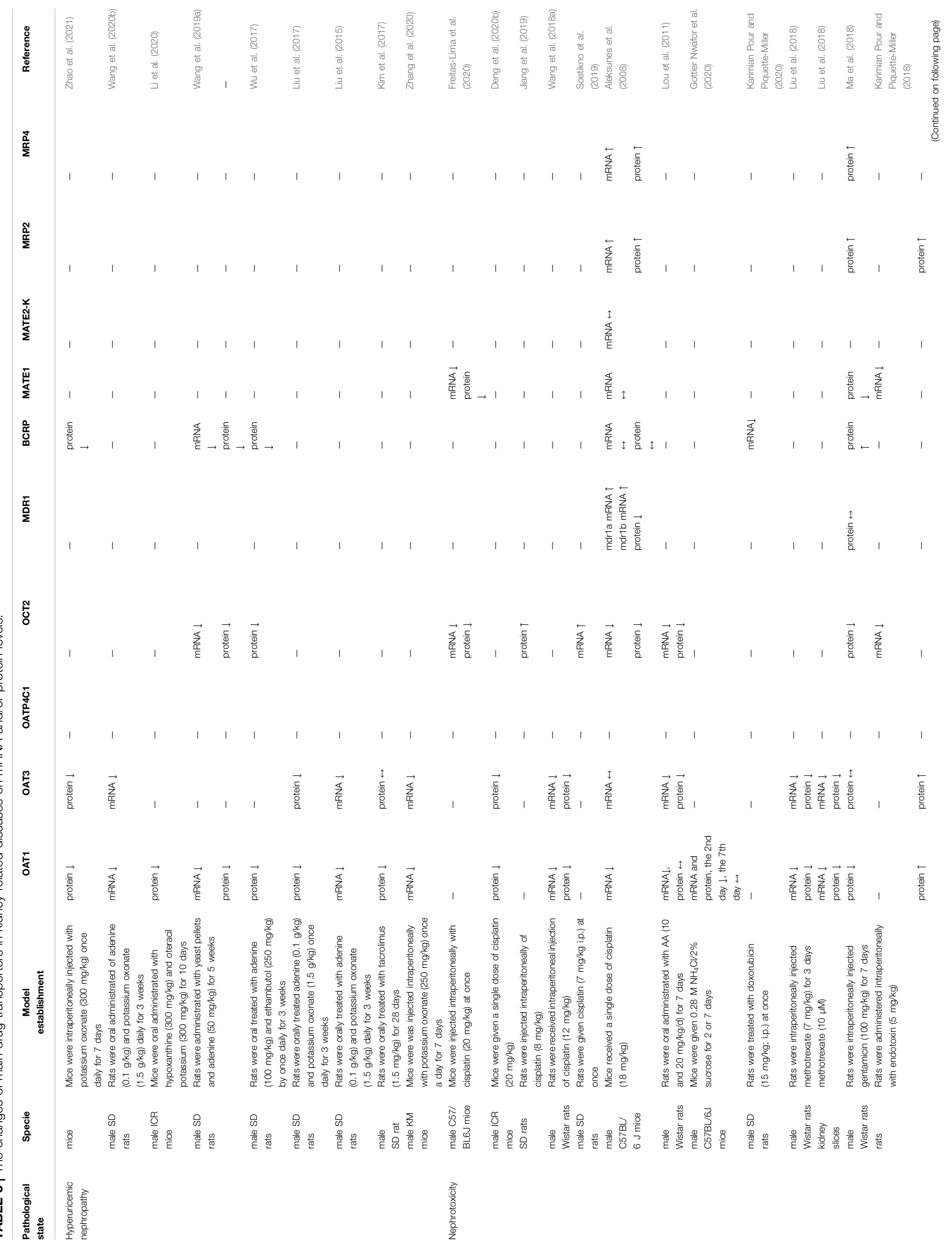


TABLE 3 | (Continued) The changes of main drug transporters in kidney related diseases on mRNA and/or protein levels.

\begin{tabular}{|c|c|c|c|c|c|c|c|c|c|c|c|c|c|}
\hline $\begin{array}{l}\text { Pathological } \\
\text { state }\end{array}$ & Specie & $\begin{array}{c}\text { Model } \\
\text { establishment }\end{array}$ & OAT1 & ОАТ3 & OATP4C1 & ост2 & MDR1 & BCRP & MATE1 & MATE2-K & MRP2 & MRP4 & Reference \\
\hline & $\begin{array}{l}\text { male } \\
\text { Wistar rats }\end{array}$ & $\begin{array}{l}\text { Rats were injected with } \mathrm{HgCl}_{2}(4 \mathrm{mg} / \mathrm{kg}) \text { at } \\
\text { once }\end{array}$ & & & & & & & & & & & $\begin{array}{l}\text { Hazelhoff and } \\
\text { Torres (2021) }\end{array}$ \\
\hline & $\begin{array}{l}\text { male } \\
\text { Wistar rats }\end{array}$ & $\begin{array}{l}\text { Rats were treated with a single injection } \\
\text { (s.c.) of } \mathrm{HgCl}_{2} \text { at a dose of } 5 \mathrm{mg} / \mathrm{kg}\end{array}$ & protein $\downarrow$ & protein $\downarrow$ & - & - & - & - & - & - & - & - & Brandoni and \\
\hline & $\begin{array}{l}\text { male } \\
\text { Wistar } \\
\text { strain rats }\end{array}$ & $\begin{array}{l}\text { Rats were injecting rats with } \mathrm{CdCl}_{2}(2 \mathrm{mg} \\
\mathrm{C} / \mathrm{kg} / \mathrm{day} \text { ) for } 14 \text { days }\end{array}$ & $\begin{array}{l}\text { mRNA } \downarrow \\
\text { protein } \downarrow\end{array}$ & $\begin{array}{l}\text { mRNA } \downarrow \\
\text { protein } \downarrow\end{array}$ & - & $\begin{array}{l}\text { mRNA } \downarrow \\
\text { protein } \downarrow\end{array}$ & - & - & - & - & - & - & $\begin{array}{l}\text { Liubojević et al. } \\
\text { (2016) }\end{array}$ \\
\hline & SD rats & $\begin{array}{l}\text { Rats were orally administrated with Zuotai } \\
(30 \mathrm{mg} / \mathrm{kg}), \mathrm{HgS}(30 \mathrm{mg} / \mathrm{kg}), \mathrm{HgCl} / \\
(34.6 \mathrm{mg} / \mathrm{kg}) \text { and } \mathrm{MeHgCl}(3.2 \mathrm{mg} / \mathrm{kg}) \text { for } \\
7 \text { days }\end{array}$ & $\begin{array}{l}\text { mRNA in } \mathrm{HgCl}_{2} \\
\text { group } \downarrow\end{array}$ & mRNA $\leftrightarrow$ & $\begin{array}{l}\text { mRNA in } \mathrm{HgCl}_{2} \\
\text { group } \downarrow\end{array}$ & mRNA $\leftrightarrow$ & $\begin{array}{l}\text { mRNA of MDR1b in } \\
\mathrm{HgCl}_{2} \text { and } \mathrm{MeHgCl} \\
\text { group } \uparrow\end{array}$ & $\begin{array}{l}\mathrm{mRNA} \\
\leftrightarrow\end{array}$ & $\begin{array}{l}\mathrm{mRNA} \\
\leftrightarrow\end{array}$ & mRNA $\leftrightarrow$ & $\begin{array}{l}\text { mRNA in } \mathrm{HgCl}_{2} \\
\text { and } \mathrm{MeHgCl} \\
\text { group } \uparrow\end{array}$ & $\begin{array}{l}\text { mRNA in } \mathrm{HgCl}_{2} \\
\text { and } \mathrm{MeHgCl} \\
\text { group } \uparrow\end{array}$ & Zhang et al. (2017a) \\
\hline & KM mice & $\begin{array}{l}\text { Mice were treated orally with Zuotai }(54 \% \\
\beta-H g S, 30 \mathrm{mg} / \mathrm{kg}), \alpha-\mathrm{HgS}(30 \mathrm{mg} / \mathrm{kg}), \\
\mathrm{HgCl}(33.6 \mathrm{mg} / \mathrm{kg}), \mathrm{MeHgCl}(3.1 \mathrm{mg} / \mathrm{kg}) \\
\text { for } 7 \text { days, respectively }\end{array}$ & mRNA $\leftrightarrow$ & $\begin{array}{l}\text { mRNA in } \\
\text { MeHgCl } \\
\text { group } \downarrow\end{array}$ & $\begin{array}{l}\mathrm{mRNA} \text { in } \\
\mathrm{MeHgCl} \text { and } \\
\mathrm{HgCl}_{2} \text { group } \downarrow\end{array}$ & - & - & - & - & $\begin{array}{l}\text { mRNA in } \\
\mathrm{HgCl}_{2} \text { and } \\
\text { MeHgCl } \\
\text { group } \uparrow\end{array}$ & $\begin{array}{l}\text { mRNA in } \mathrm{HgCl}_{2} \\
\text { and } \mathrm{MeHgCl} \\
\text { group } \uparrow\end{array}$ & $\begin{array}{l}\text { mRNA in } \mathrm{HgCl}_{2} \\
\text { and } \mathrm{MeHgCl} \\
\text { group } \uparrow\end{array}$ & Liu et al. (2016) \\
\hline \multirow[t]{5}{*}{$\begin{array}{l}\text { Ischemia- } \\
\text { Reperfusion in } \\
\text { kidney }\end{array}$} & $\begin{array}{l}\text { female SD } \\
\text { rats }\end{array}$ & $\begin{array}{l}\text { Rats model was induced by bilateral } \\
\text { clamping of renal arteries for } 45 \mathrm{~min}\end{array}$ & $\begin{array}{l}\mathrm{mRNA} 6 \text { and } 24 \mathrm{~h} \\
\downarrow, 72 \mathrm{~h} \leftrightarrow\end{array}$ & $\begin{array}{l}\text { mRNA } 6 \text { and } \\
24 \mathrm{hl} \text {, } \\
72 \mathrm{~h} \leftrightarrow\end{array}$ & - & - & - & - & - & - & - & - & $\begin{array}{l}\text { Schneider et al. } \\
\text { (2007) }\end{array}$ \\
\hline & $\begin{array}{l}\text { male SD } \\
\text { rats }\end{array}$ & $\begin{array}{l}\text { Rat model was induced by vascular } \\
\text { clamps over both pedicles for } 30 \mathrm{~min}\end{array}$ & $\begin{array}{l}\text { mRNA } \downarrow \\
\text { protein } \downarrow\end{array}$ & $\begin{array}{l}\text { mRNA } \downarrow \\
\text { protein } \downarrow\end{array}$ & - & - & protein $\leftrightarrow$ & - & - & - & - & - & $\begin{array}{l}\text { Matsuzaki et al. } \\
\text { (2007) }\end{array}$ \\
\hline & $\begin{array}{l}\text { male SD } \\
\text { rats }\end{array}$ & $\begin{array}{l}\text { Rats were induced using vascular clamps } \\
\text { over both pedicles for } 30 \text { min }\end{array}$ & $\begin{array}{l}\text { mRNA } \downarrow \\
\text { protein } \downarrow\end{array}$ & $\begin{array}{l}\text { mRNA } \downarrow \\
\text { protein } \downarrow\end{array}$ & - & $\begin{array}{l}\text { mRNA } \downarrow \\
\text { protein } \downarrow\end{array}$ & - & - & $\begin{array}{l}\text { mRNA } \downarrow \\
\text { protein } \\
\downarrow\end{array}$ & - & - & - & $\begin{array}{l}\text { Matsuzaki et al. } \\
\text { (2008) }\end{array}$ \\
\hline & $\begin{array}{l}\text { male } \\
\text { Wistar rats }\end{array}$ & $\begin{array}{l}\text { Rats were induced by occluding renal } \\
\text { pedicles for } 60 \mathrm{~min}\end{array}$ & protein $\downarrow$ & protein $\downarrow$ & - & - & - & - & - & - & - & - & $\begin{array}{l}\text { Brandoni and } \\
\text { Torres (2015) }\end{array}$ \\
\hline & $\begin{array}{l}\text { male FVB } \\
\text { mice }\end{array}$ & $\begin{array}{l}\text { Mice was induced by bilateral clamping of } \\
\text { the renal artery and vein for } 30 \mathrm{~min}\end{array}$ & - & - & - & - & protein $\downarrow$ & $\begin{array}{l}\text { mRNA } \\
\downarrow \\
\text { protein } \\
\downarrow\end{array}$ & - & - & protein $\downarrow$ & protein $\downarrow$ & Huls et al. (2006) \\
\hline \multirow[t]{4}{*}{$\begin{array}{l}\text { Chronic Renal } \\
\text { Failure }\end{array}$} & $\begin{array}{l}\text { Male SD } \\
\text { rats }\end{array}$ & $\begin{array}{l}\text { model rats were induced by two-stage } 5 / 6 \\
\text { nephrectomy }\end{array}$ & mRNA $\downarrow$ & mRNA $\downarrow$ & - & - & - & - & - & - & - & - & Kong et al. (2017) \\
\hline & Wistar rats & a 5/6 nephrectomy & - & - & - & - & - & $\begin{array}{l}\text { mRNA } \\
\downarrow \\
\text { protein }\end{array}$ & - & - & - & - & Nagura et al. (2016) \\
\hline & $\begin{array}{l}\text { Male SD } \\
\text { rats }\end{array}$ & $\begin{array}{l}\text { Rats were undergone subtotal } \\
\text { nephrectomy operation ( } 80 \% \text { renal } \\
\text { ablation) }\end{array}$ & - & - & - & - & $\begin{array}{l}\text { protein } 3 \text { and } \\
6 \text { weeks } \downarrow\end{array}$ & $\downarrow$ & - & - & $\begin{array}{l}\text { protein } 3 \text { weeks } \downarrow \text {, } \\
6 \text { weeks } \leftrightarrow\end{array}$ & - & Laouari et al. (2001) \\
\hline & $\begin{array}{l}\text { male } \\
\text { Wistar } \\
\text { albino rats }\end{array}$ & $\begin{array}{l}\text { model rats were undergone } 5 / 6 \\
\text { nephrectomy operation }\end{array}$ & protein $\leftrightarrow$ & protein $\leftrightarrow$ & - & protein $\downarrow$ & - & - & - & - & - & - & Ji et al. (2002) \\
\hline $\begin{array}{l}\text { Nephrotic } \\
\text { Syndrome }\end{array}$ & $\begin{array}{l}\text { male SD } \\
\text { rats }\end{array}$ & $\begin{array}{l}\text { rats were intravenously injected with } \\
\text { adriamycin }(6 \mathrm{mg} / \mathrm{kg} \text { ) for once }\end{array}$ & $\begin{array}{l}\text { mRNA and } \\
\text { protein, } 6,9 \text { and } \\
12 \text { weeks } \downarrow\end{array}$ & - & - & $\begin{array}{l}\text { mRNA and protein, } 6 \\
\text { and } 9 \text { weeks } \downarrow \\
12 \text { weeks } \uparrow\end{array}$ & $\begin{array}{l}\text { mRNA and protein, } \\
6 \text { weeks } \downarrow, 9 \text { weeks } \\
\leftrightarrow \text { and } 12 \text { weeks } \leftrightarrow\end{array}$ & - & - & - & $\begin{array}{l}\text { mRNA and } \\
\text { protein, } 6 \text { and } \\
9 \text { weeks } \downarrow \text {, } \\
12 \text { weeks } \uparrow\end{array}$ & $\begin{array}{l}\text { mRNA and } \\
\text { protein, } 6 \text { and } \\
9 \text { weeks } \downarrow \text {, } \\
12 \text { weeks } \uparrow\end{array}$ & Dong et al. (2020) \\
\hline $\begin{array}{l}\text { Obstructive } \\
\text { nephropathy }\end{array}$ & $\begin{array}{l}\text { male } \\
\text { Wistar rats }\end{array}$ & $\begin{array}{l}\text { The ureteral obstruction was released } \\
\text { after } 24 \mathrm{~h}\end{array}$ & protein $\downarrow$ & protein $\downarrow$ & - & - & - & - & - & - & - & - & $\begin{array}{l}\text { Brandoni and } \\
\text { Torres (2015) }\end{array}$ \\
\hline $\begin{array}{l}\text { Renal } \\
\text { transplantation }\end{array}$ & $\begin{array}{l}\text { male LBN } \\
\text { and LEW } \\
\text { rats }\end{array}$ & $\begin{array}{l}\text { kidneys of LBN rats were transplanted into } \\
\text { LEW rats }\end{array}$ & - & - & - & $\begin{array}{l}\text { mRNA and protein in } \\
\text { allogeneic } \\
\text { transplantation } \downarrow\end{array}$ & - & - & - & - & - & - & $\begin{array}{l}\text { Ciarimboli et al. } \\
\text { (2013) }\end{array}$ \\
\hline
\end{tabular}

SD rats: Sprague-Dawley rats; KM mice: kunming mice; FVB mice: Friend leukaemia virus B strain mice; LBN rats: lewis brown norway rats; LEW rats: lewis rats; $\downarrow$ : decrease in expression; $\uparrow:$ increase in expression; $\leftrightarrow:$ no significant difference; I: not mentioned. 
TABLE 4 | The changes of main drug transporters in liver and gallbladder related diseases on mRNA and/or protein levels.

\begin{tabular}{|c|c|c|c|c|c|c|c|c|c|c|}
\hline $\begin{array}{l}\text { Pathological } \\
\text { state }\end{array}$ & Species & $\begin{array}{c}\text { Model } \\
\text { establishment }\end{array}$ & OAT1 & ОАТ3 & Ост2 & MDR1 & BCRP & MRP2 & MRP4 & Reference \\
\hline \multirow[t]{8}{*}{$\begin{array}{l}\text { Nonalcoholic } \\
\text { steatohepatitis }\end{array}$} & $\begin{array}{l}\text { male } \\
\text { C57BL/ } \\
\text { 6Jmice }\end{array}$ & $\begin{array}{l}\text { Mice were fed with a } \\
\text { methionine choline- } \\
\text { deficient diet for } 4 \text { weeks }\end{array}$ & $\begin{array}{l}\text { mRNA } \downarrow \\
\text { protein } \leftrightarrow\end{array}$ & $\mathrm{mRNA} \leftrightarrow$ & $\begin{array}{l}\mathrm{mRNA} \\
\downarrow\end{array}$ & $\begin{array}{l}\text { MDR1a } \\
\text { mRNA } \uparrow \\
\text { protein } \uparrow\end{array}$ & $\begin{array}{l}\mathrm{mRNA} \\
\leftrightarrow \\
\text { protein } \\
\leftrightarrow\end{array}$ & $\mathrm{mRNA} \leftrightarrow$ & $\begin{array}{l}\text { mRNA } \uparrow \\
\text { protein } \uparrow\end{array}$ & $\begin{array}{l}\text { Canet et al. } \\
(2015)\end{array}$ \\
\hline & $\begin{array}{l}\text { male } \\
\text { C57BL/ } \\
\text { 6J mice }\end{array}$ & $\begin{array}{l}\text { Mice were fed with a high- } \\
\text { fat diet for } 8 \text { weeks }\end{array}$ & $\begin{array}{l}\text { mRNA } \downarrow \\
\text { protein } \leftrightarrow\end{array}$ & mRNA $\leftrightarrow$ & $\begin{array}{l}\mathrm{mRNA} \\
\uparrow\end{array}$ & $\begin{array}{l}\text { MDR1a } \\
\text { mRNA } \uparrow \\
\text { protein } \\
\leftrightarrow\end{array}$ & $\begin{array}{l}\text { mRNA } \\
\leftrightarrow \\
\text { protein } \\
\downarrow\end{array}$ & $\mathrm{mRNA} \leftrightarrow$ & $\begin{array}{l}\mathrm{mRNA} \leftrightarrow \\
\text { protein } \\
\leftrightarrow\end{array}$ & $\begin{array}{l}\text { Canet et al. } \\
(2015)\end{array}$ \\
\hline & $\begin{array}{l}\text { ob/ob } \\
\text { mice }\end{array}$ & $\begin{array}{l}\text { Mice were fed with a } \\
\text { methionine choline- } \\
\text { deficient diet for } 4 \text { weeks }\end{array}$ & $\begin{array}{l}\text { mRNA } \downarrow \\
\text { protein } \leftrightarrow\end{array}$ & $\mathrm{mRNA} \uparrow$ & $\begin{array}{l}\text { mRNA } \\
\downarrow\end{array}$ & $\begin{array}{l}\text { MDR1a } \\
\text { mRNA } \uparrow \\
\text { protein } \uparrow\end{array}$ & $\begin{array}{l}\text { mRNA } \\
\leftrightarrow \\
\text { protein } \\
\leftrightarrow\end{array}$ & $\mathrm{mRNA} \leftrightarrow$ & $\begin{array}{l}\text { mRNA } \uparrow \\
\text { protein } \uparrow\end{array}$ & $\begin{array}{l}\text { Canet et al. } \\
(2015)\end{array}$ \\
\hline & $\begin{array}{l}\mathrm{db} / \mathrm{db} \\
\text { mice }\end{array}$ & $\begin{array}{l}\text { Mice were fed with a } \\
\text { methionine choline- } \\
\text { deficient diet for } 8 \text { weeks }\end{array}$ & $\begin{array}{l}\text { mRNA } \downarrow \\
\text { protein } \leftrightarrow\end{array}$ & $\mathrm{mRNA} \uparrow$ & $\begin{array}{l}\mathrm{mRNA} \\
\downarrow\end{array}$ & $\begin{array}{l}\text { MDR1a } \\
\text { mRNA } \uparrow \\
\text { protein } \uparrow\end{array}$ & $\begin{array}{l}\mathrm{mRNA} \\
\leftrightarrow \\
\text { protein } \\
\leftrightarrow\end{array}$ & mRNA $\uparrow$ & $\begin{array}{l}\text { mRNA } \uparrow \\
\text { protein } \uparrow\end{array}$ & $\begin{array}{l}\text { Canet et al. } \\
(2015)\end{array}$ \\
\hline & $\begin{array}{l}\text { male SD } \\
\text { rats }\end{array}$ & $\begin{array}{l}\text { Rats were fed with a } \\
\text { methionine choline- } \\
\text { deficient diet for } 4 \text { weeks }\end{array}$ & $\begin{array}{l}\text { mRNA } \leftrightarrow \\
\text { protein } \leftrightarrow\end{array}$ & $\mathrm{mRNA} \uparrow$ & $\begin{array}{l}\text { mRNA } \\
\leftrightarrow\end{array}$ & $\begin{array}{l}\text { MDR1a } \\
\text { mRNA } \uparrow \\
\text { protein } \uparrow\end{array}$ & $\begin{array}{l}\text { mRNA } \\
\uparrow \\
\text { protein } \\
\leftrightarrow\end{array}$ & $\begin{array}{l}\text { mRNA } \uparrow \\
\text { protein } \uparrow\end{array}$ & $\begin{array}{l}\mathrm{mRNA} \uparrow \\
\text { protein } \\
\leftrightarrow\end{array}$ & $\begin{array}{l}\text { Canet et al. } \\
(2015)\end{array}$ \\
\hline & $\begin{array}{l}\text { male SD } \\
\text { rats }\end{array}$ & $\begin{array}{l}\text { Rats were fed with a high- } \\
\text { fat diet for } 8 \text { weeks }\end{array}$ & $\begin{array}{l}\text { mRNA } \leftrightarrow \\
\text { protein } \leftrightarrow\end{array}$ & $\mathrm{mRNA} \leftrightarrow$ & $\begin{array}{l}\text { mRNA } \\
\leftrightarrow\end{array}$ & $\begin{array}{l}\text { MDR1a } \\
\text { mRNA } \\
\leftrightarrow \\
\text { protein } \uparrow\end{array}$ & $\begin{array}{l}\text { mRNA } \\
\leftrightarrow \\
\text { protein } \\
\leftrightarrow\end{array}$ & protein $\leftrightarrow$ & $\begin{array}{l}\text { protein } \\
\leftrightarrow\end{array}$ & $\begin{array}{l}\text { Canet et al. } \\
(2015)\end{array}$ \\
\hline & $\mathrm{fa} / \mathrm{fa}$ rats & $\begin{array}{l}\text { Rats were fed with a high- } \\
\text { fat diet for } 8 \text { weeks }\end{array}$ & $\mathrm{mRNA} \leftrightarrow$ & $\mathrm{mRNA} \leftrightarrow$ & $\begin{array}{l}\text { mRNA } \\
\leftrightarrow\end{array}$ & $\begin{array}{l}\text { MDR1a } \\
\text { mRNA } \\
\leftrightarrow\end{array}$ & $\begin{array}{l}\text { mRNA } \\
\leftrightarrow\end{array}$ & $\mathrm{mRNA} \leftrightarrow$ & $\mathrm{mRNA} \leftrightarrow$ & $\begin{array}{l}\text { Canet et al. } \\
(2015)\end{array}$ \\
\hline & & & protein $\leftrightarrow$ & & & $\begin{array}{l}\text { protein } \\
\leftrightarrow\end{array}$ & $\begin{array}{l}\text { protein } \\
\downarrow\end{array}$ & protein $\leftrightarrow$ & $\begin{array}{l}\text { protein } \\
\leftrightarrow\end{array}$ & \\
\hline $\begin{array}{l}\text { Ischemia- } \\
\text { reperfusion- } \\
\text { induced in liver }\end{array}$ & $\begin{array}{l}\text { male SD } \\
\text { rats }\end{array}$ & $\begin{array}{l}\text { Rats were undergone } \\
\text { hepatic ischemia for } \\
60 \text { min }\end{array}$ & - & - & - & - & - & $\begin{array}{l}\text { mRNA } 3 \mathrm{~h} \\
\uparrow, 6 \mathrm{~h} \uparrow, \\
24 \mathrm{~h} \leftrightarrow, \\
48 \mathrm{~h} \leftrightarrow \\
\text { protein } \\
3 \mathrm{~h} \leftrightarrow, 6 \mathrm{~h} \\
\uparrow, 24 \mathrm{~h} \uparrow, \\
48 \mathrm{~h} \leftrightarrow\end{array}$ & $\begin{array}{l}\mathrm{mRNA} \\
3 \mathrm{~h} \leftrightarrow, \\
6 \mathrm{~h} \uparrow, \\
24 \mathrm{~h} \leftrightarrow, \\
48 \mathrm{~h} \leftrightarrow \\
\text { protein } \\
3 \mathrm{~h} \leftrightarrow, \\
6 \mathrm{~h} \leftrightarrow, \\
24 \mathrm{~h} \uparrow, \\
48 \mathrm{~h} \leftrightarrow\end{array}$ & $\begin{array}{l}\text { Tanaka } \\
\text { et al. (2008) }\end{array}$ \\
\hline \multirow[t]{4}{*}{$\begin{array}{l}\text { Extrahepatic } \\
\text { Cholestasis }\end{array}$} & $\begin{array}{l}\text { male } \\
\text { C57BL/6 } \\
\text { mice }\end{array}$ & $\begin{array}{l}\text { Mice were undergone a } \\
\text { bile-duct operation for } 1 \text {, } \\
3,7 \text {, and } 14 \text { days }\end{array}$ & - & - & - & - & - & $\begin{array}{l}\mathrm{mRNA} \\
1 \text { day } \uparrow, 3, \\
7 \text { and } \\
14 \text { days } \\
\leftrightarrow\end{array}$ & $\mathrm{mRNA} \uparrow$ & $\begin{array}{l}\text { Slitt et al. } \\
(2007)\end{array}$ \\
\hline & $\begin{array}{l}\text { male } \\
\text { Wistar } \\
\text { rats }\end{array}$ & $\begin{array}{l}\text { Rats were undergone a } \\
\text { bile-duct operation } \\
\text { for } 21 \mathrm{~h}\end{array}$ & $\begin{array}{l}\text { protein in cortex } \\
\text { homogenates } \uparrow \\
\text { protein in } \\
\text { basolateral } \\
\text { membranes } \uparrow\end{array}$ & $\begin{array}{l}\text { protein in cortex } \\
\text { homogenates } \uparrow \\
\text { protein in } \\
\text { basolateral } \\
\text { membranes } \leftrightarrow\end{array}$ & - & - & - & - & - & $\begin{array}{l}\text { Brandoni } \\
\text { et al. (2006) }\end{array}$ \\
\hline & $\begin{array}{l}\text { Male } \\
\text { Wistar } \\
\text { rats }\end{array}$ & $\begin{array}{l}\text { Rats were undergone a } \\
\text { bile-duct operation for } 24 \text {, } \\
72 \text { and } 120 \mathrm{~h}\end{array}$ & - & - & - & - & - & - & $\begin{array}{l}\text { protein } \\
24,72 \\
\text { and } \\
120 \mathrm{~h} \uparrow\end{array}$ & $\begin{array}{l}\text { Tanaka } \\
\text { et al. (2002) }\end{array}$ \\
\hline & $\begin{array}{l}\text { Male } \\
\text { Wistar } \\
\text { rats }\end{array}$ & $\begin{array}{l}\text { Rats was injected (i.p.) } \\
\text { with alpha- } \\
\text { naphthylisothiocyanate } \\
(50 \mathrm{mg} / \mathrm{kg})\end{array}$ & $\begin{array}{l}\text { mRNA } \downarrow \\
\text { protein } \downarrow\end{array}$ & $\begin{array}{l}\text { mRNA } \downarrow \\
\text { protein } \downarrow\end{array}$ & - & - & - & $\begin{array}{l}\text { mRNA } \uparrow \\
\text { protein } \uparrow\end{array}$ & - & $\begin{array}{l}\text { Liu et al. } \\
\text { (2012) }\end{array}$ \\
\hline
\end{tabular}

SD rats: Sprague-Dawley rats; ob/ob mice: B6.Cg-Lep,ob./J mice; db/db mice: B6.BKS(D)-Lepr,db./J mice; fa/fa rats: Crl:ZUC-Lepr,fa. fatty rats; $\downarrow$ : decrease in expression; $\uparrow:$ increase in expression; ↔: no significant difference; /: not mentioned. 


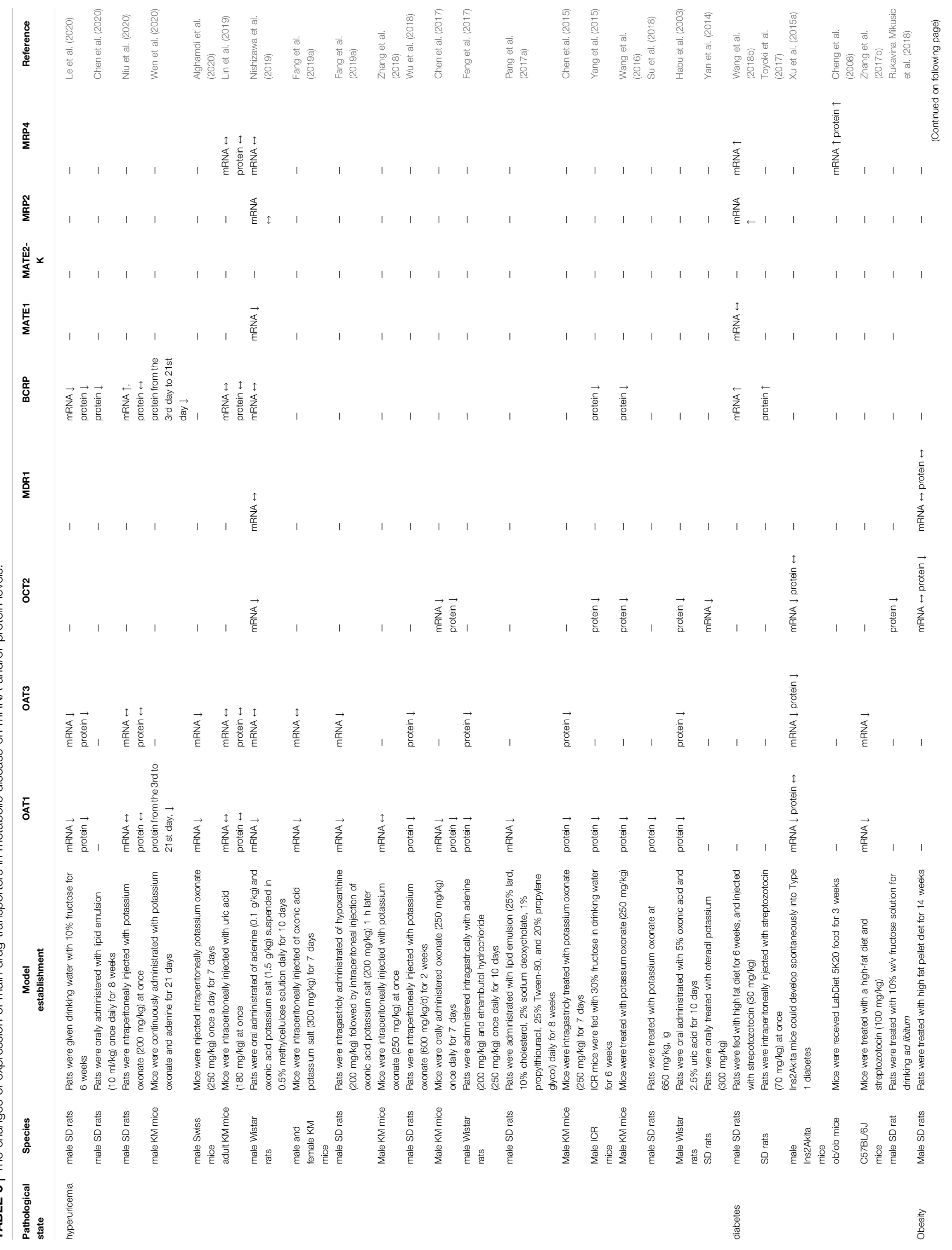




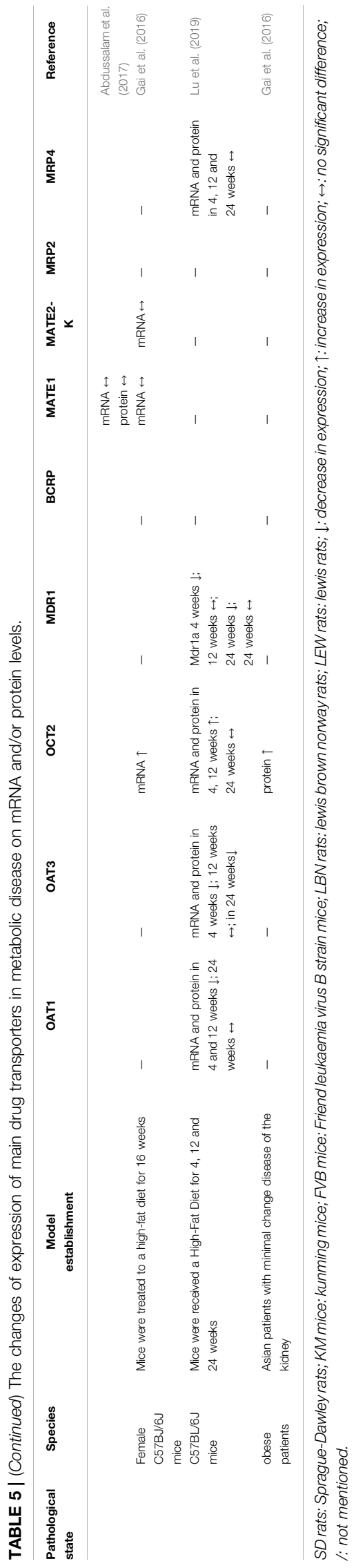

Uric acid nephropathy, mainly caused by hyperuricemia, is a common kidney disease associated with hypertension, proteinuria, oedema, etc. (Perry et al., 1976). In animal experiments, adenine and potassium oxonate are often employed to construct uric acid nephropathy models for drug screening, development, and drug interaction research (Liu et al., 2017; Wu et al., 2017; Wang et al., 2020b). To date, OAT1 and OAT3 are the two most studied drug transporters in uric acid nephropathy, as these proteins are responsible effects for uric acid excretion. Reduced OAT1/3 mRNA and protein levels are consistently noted in uric acid nephropathy (Liu et al., 2015; Liu et al., 2017; Wang et al., 2020b; Zhang et al., 2020). The same trend was observed in the uptake transporter OCT2 and efflux transporter BCRP (Wu et al., 2017; Wang et al., 2019a). Nephrotoxic substances, such as cisplatin, gentamicin, and heavy metals, are causative agents of AKI in clinic. In the cisplatin-induced nephrotoxicity model, the mRNA and protein levels of renal OAT1/3 were decreased in both rats and mice, which could prevent the absorption of cisplatin from blood into renal tubular epithelial cell (Wang et al., 2018a; Deng et al., 2020b). MATE1 is an efflux transporter that mediates the excretion of cisplatin from renal tubules into urine. Previous study has proved that the survival time of $\mathrm{Mate}^{-/-}$mice was significantly shorter than that of the control group. After cisplatin administration, the blood concentration and accumulation in the kidney of $\mathrm{Mate}^{-/-}$mice were higher than that in the control mice. Using combination of cisplatin and the MATEs inhibitor pyrimethamine was found to be more nephrotoxic than using cisplatin alone. These results suggest that MATE1 mediates the renal excretion of cisplatin and participates in its nephrotoxicity (Kusuhara et al., 2011; Song et al., 2016). However, OCT2 mRNA and protein levels exhibited the species differences, which were decreased in mice but were increased in rats (Aleksunes et al., 2008; Soetikno et al., 2019). It is worth noting that mRNA and protein levels may also show different trends during the course of disease. For instance, oral administration of $\mathrm{NH}_{4} \mathrm{Cl}$ caused downregulation of OAT1 mRNA and protein levels on the 2nd day, but the levels returned to its original levels on the $7^{\text {th }}$ day (Gottier Nwafor et al., 2020). In the model of heavy metal-induced nephrotoxicity, the uptake transporters OAT1/3, OATP4C1, and OCT2 showed decreasing trends, whereas the efflux transporters MDR1, MATE2-K, and MRP2/4 showed increasing trends (Liu et al., 2016; Ljubojević et al., 2016; Zhang et al., 2017a), which decreased absorption, enhanced urinary clearance of heavy metals, and prevented accumulation in the kidney. Ischemia-reperfusion injury (IRI) in the kidney is another most common clinical cause of AKI, which often occurs during the clinical course of shock, acute renal artery occlusion, or renal transplantation. At present, the nonclinical IRI model is usually constructed by sealing the bilateral renal pedicle with a mini-artery clip (Shiva et al., 2020). Interestingly, the drug transporters OAT1/3, OCT2, MDR1, MATE1, and MRP2/4 in this model showed reducing trends. Schneider et al. (2007) reported that the OAT1/ 3 levels are associated with recovery time after IRI in kidney. Compared with the sham group, OAT1/3 mRNA and protein levels were completely restored to the preoperative level after 7 days postischemic reperfusion. Given that renal OAT1/3 play significant roles in the excretion of many anionic drugs, IRI induced AKI changes the pharmacokinetics of these drugs, 
including increases in plasma levels and $t_{1 / 2}$. An animal model with $5 / 6$ nephrectomy is often used to simulate chronic renal failure in humans. Previous studies have reported the downregulation of uptake transporters OAT1/3 and OCT2, as well as the downregulation of efflux transporters MDR1, BCRP, and MRP2 in animal kidneys during the disease statuses (Laouari et al., 2001; Nagura et al., 2016; Kong et al., 2017). Nephrotic syndrome (NS) is a group of clinical symptoms characterized by increased glomerular basement membrane permeability, high proteinuria, hypoproteinemia, high oedema, and hyperlipidemia (Hull and Goldsmith, 2008). During the 12-week experiment, OAT1 mRNA and protein levels consistently exhibited trends of reduction. OCT2 protein level showed a downward trend within 9 weeks, but increased in the 12th week. The same trends were observed in MRP2 and MRP4 (Dong et al., 2020). The unilateral ureteral obstruction (UUO) animal model is often used to simulate clinical obstructive nephropathy. A study reported reduced OAT1/3 protein levels in the UUO model, indicating reduced renal excretion rates and pharmacokinetic changes of some drugs (Brandoni and Torres, 2015). Downregulation of OCT2 protein level was observed in the kidney transplanted rats. Atenolol, pindolol, and ofloxacin are the substrates of OCT2, and their appropriate doses are difficult to achieve in kidney transplanted patients (Ciarimboli et al., 2013).

In summary, in renal-related diseases, the expressions of OAT1/3 transporters are invariably reduced. The OAT1/3 are responsible for the uptake of endogenous and/or exogenous substances from the blood into renal tubular epithelial cells. The reduction in the renal-related diseases is like a doubleedged sword. On the one hand, it prevents some toxic substances (e.g., indole sulfate) from entering renal tissue during the kidney injury, subsequently reduces renal damage, and thus plays a role in protecting the kidney. On the other hand, it also reduced drug excretion, resulting in increased drug concentration in plasma, which leads to toxic side effects. Clinical pharmacokinetics of morinidazole has proved that sulfate conjugate of morinidazole M7 was a substrate of OAT1 and OAT3, while the glucuronide conjugates of M8-1 and M8-2 were substrates of OAT3. After intravenous infusion of $500 \mathrm{mg}$ morinidazole, the area under the curve (AUC) values for M7, M81, and M8-2 were 15.1-, 20.4-, and 17.4-fold, respectively, higher in patients with severe renal impairment than those in healthy subjects (Zhong et al., 2014; Kong et al., 2017). The expressions of efflux transporters are different in different renal diseases. It is noteworthy that the increased MRP2/4 in nephrotoxic pathology will transfer the toxic substances from renal tubular epithelial cells into the urine to exert the detoxification effect. However, the increased MRP2/4 also promote the transfer of some therapeutic drugs. Therefore, both changes should be carefully considered in the treatment of the renal-related diseases.

\section{Effect of Liver and Gallbladder-Related Diseases on Drug Transporters in Kidney}

The Inner Canon of Huangdi, an ancient Chinese medical scripture that is the basis for traditional Chinese medicine, states that "the liver and kidney are homologous." This means that, although the structure and function of the liver and kidney are different, they exhibit a close relationship based on physiological and pathological features. For example, renal injury is often also associated with liverrelated diseases, such as hepatorenal syndrome (Raj et al., 2020; Simonetto et al., 2020). In Table 4, we have summarized the characteristics of nonalcoholic fatty liver disease (NAFLD), ischemia reperfusion (IR), and bile duct obstruction pathology on renal drug transporters, providing information for optimizing the drug prescriptions. NAFLD is a global disease (with an approximately $25 \%$ of global incidence rate) induced by many factors except alcohol and other specific factors, characterized by excessive deposition of fat in hepatocytes (Younossi et al., 2016). Nonclinical NAFLD models have shown that OAT1 mRNA expression was decreased in mice, but no significant difference was found in rats. Elevated OAT3, MDR1, and MPR2/4 mRNA expression levels were observed in both mouse and rat models, but BCRP protein level was decreased (Canet et al., 2015). Clinical treatments for NAFLD typically include metformin, vitamin $\mathrm{E}$, and statins to exert anti-IR, antioxidant, and lipid-lowering effects. Clarke et al. (2015) revealed that metformin exposure is increased in nonalcoholic steatohepatitis mice model ( $60 \%$ of metformin dose excreted in urine) than that in control group (82\% of metformin dose excreted in urine), which might be caused by the decreases of OCT2 and MATE1 in the kidneys of disease mice. In patients, $25 \%$ of NASH may lead to an impaired kidney function that highlights a need to adjust drug dosage (Targher et al., 2010). A recent research showed that the novel targeting therapeutic agents mainly target peroxisome proliferator-activated receptors (PPARs), farnesoid X receptor (FXR), and glucagon-like-1 (GLP-1) (Zhou et al., 2020b). As one of the subtypes of PPARs, PPARa is widely expressed in the liver, adipose tissue, heart, skeletal muscle, and kidney. Given that PPARa has a regulatory effect on the drug transporters MATE1 and OCT2 (Freitas-Lima et al., 2020), attention should be given to drug disposition in vivo during the clinical use of this novel drug simultaneously with other drugs. IRI of the liver is an inevitable complication during liver resection and liver transplantation. The animal model confirmed that hepatic IRI could increase the kidney MRP2/4 levels (Tanaka et al., 2008). Interestingly, the increases of proteins showed obvious delays, compared to those of mRNAs. The increased renal MRP2 accompanied with decreased hepatic MRP2 may protect against oxidative stress and inflammation after hepatic IRI. Extrahepatic cholestasis is a pathophysiological process caused by the obstruction of bile secretion and excretion. This disease status could induce the expressions of the efflux transporter MRP2/4 in the kidney which will promote the excretion of bile acids and some therapeutic drugs (Slitt et al., 2007). OAT1/3 levels are different in various animal models, which may be related to the way and/or time of modeling (Brandoni et al., 2006; Liu et al., 2012). In general, with liver and bile duct-related diseases, the expressions of MRP2/4 are increased, which accelerates the excretion of endogenous/exogenous toxic substances in the kidney to play a protective role in the body.

\section{Effect of Metabolic Disease on Drug Transporters in Kidney}

As shown in Table 5, metabolic diseases can also cause changes in drug transporters in the kidney. Hyperuricemia is a chronic metabolic disease caused by purine metabolism disorder, and 


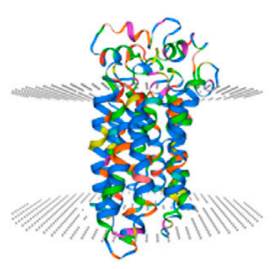

OAT1 (UniProtKB AC Q4U2R8) (UniProtKB AC Q8TCC7)

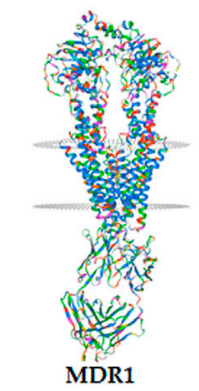

(UniProtKB AC P08183) (UniProtKB AC Q9UNQ0)
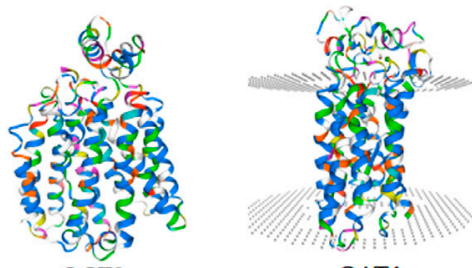

OAT4

(UniProtKB AC 015244) (UniProtKB AC Q9NSA0) (UniProtKB AC Q96FL8)

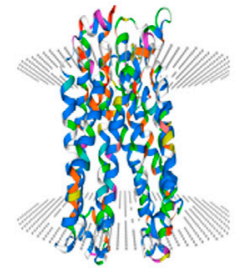

MATE2-K

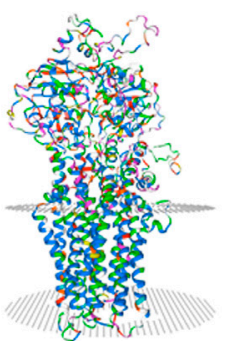

MRP2
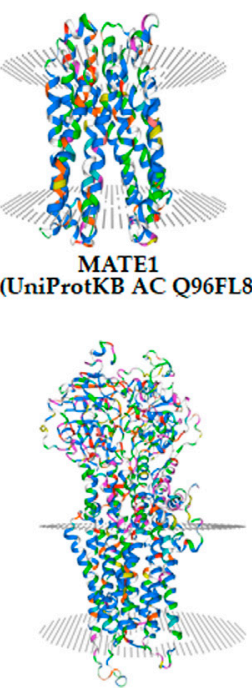

MRP4
(UniProtKB AC Q86VL8) (UniProtKB AC Q92887) (UniProtKB AC O15439)

FIGURE 3 | The homology models of OAT1, OAT3, OCT2, MDR1, BCRP, MATE1, MATE2-K, OAT4, MRP2, and MRP4 in human from SWISS-MODEL (https:// swissmodel.expasy.org/).

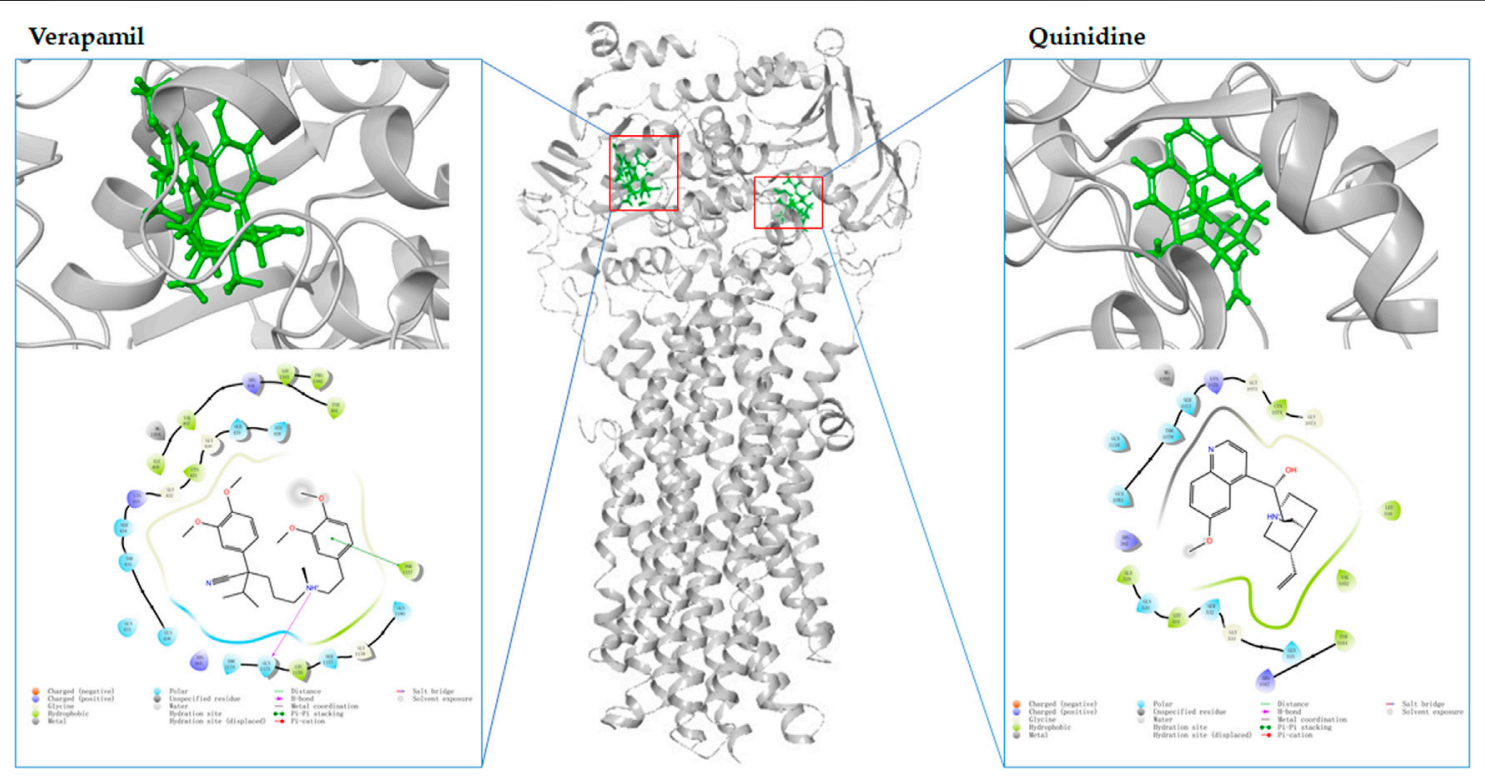

FIGURE 4 | The molecular docking of MDR1 (gray, PDB:6COV) with verapamil (green left) and quinidine (green, right) by MAESTRO Schrödinger released in 2017-1.

the condition is primarily caused by excessive production and reduced excretion of uric acid. A cross-sectional study in China reported that, with the improvement of people's quality of life, the prevalence of hyperuricemia has increased from approximately $26.1 \%$ in 2010 to approximately $34.4 \%$ in 2019 among men in Wuhan city (Wan et al., 2021). High uric acid level is associated with hypertension, CKD, obesity, metabolic syndrome, etc. Therefore, a combined medication is a common treatment for hyperuricemia. Thus, the levels of renal transporters should attract clinician attentions. In animal models, the OAT1/3, OCT2, and BCRP expressions are decreased under the pathological condition, whereas MDR1 and MRP2/4 expressions are not affected by hyperuricemia (Nishizawa et al., 2019; Le et al., 2020). A growing number of studies have reported that OAT1/3, OCT2, and BCRP are involved in urate efflux from epithelial cells to urine (Taniguchi et al., 2021), and 
TABLE 6 | Summary of published molecular docking models for assessing the substrates and inhibitors of drug transporters.

\begin{tabular}{|c|c|c|c|c|}
\hline Transporters & $\begin{array}{l}\text { Type of } \\
\text { compounds }\end{array}$ & $\begin{array}{l}\text { No. of compounds for } \\
\text { test }\end{array}$ & Descriptors & Reference \\
\hline \multirow[t]{2}{*}{ OAT1 } & inhibitors & 22 natural compounds & $\begin{array}{l}\text { A eukaryotic phosphate transporter from Piriformospora } \\
\text { indica (Protein Data Bank ID: 4J05) was used as OAT1 }\end{array}$ & Wang et al. (2018c) \\
\hline & substrates & 2 aristolochic acid analogues & $\begin{array}{l}\text { The homology modeling of OAT1 was conducted using } \\
\text { SWISS MODEL. Docking was performed using LeDock } \\
\text { software }\end{array}$ & Ji et al. (2020) \\
\hline \multirow[t]{2}{*}{ OAT3 } & inhibitors & 22 natural compounds & $\begin{array}{l}\text { The structure of Escherichia coli multidrug resistance } \\
\text { transporter MdfA (Protein Data Bank ID: 4ZP2) were used } \\
\text { as OAT3 }\end{array}$ & Wang et al. (2018c) \\
\hline & substrates & 3 dicaffeoylquinic acids & $\begin{array}{l}\text { Escherichia coli multidrug resistance transporter MdfA } \\
\text { (PDB ID: 4ZP2) was used as OAT3 for homology } \\
\text { modeling }\end{array}$ & Wang et al. (2019b) \\
\hline OCT2 & substrates & 14 coupounds & $\begin{array}{l}\text { The rbOCT2 sequence was used as a "probe" to search } \\
\text { homologous sequences (PSI-BLAST, NCBI database) } \\
\text { and sequence-based structural relatives (3D-PSSM) }\end{array}$ & Zhang et al. (2005) \\
\hline \multirow[t]{20}{*}{ MDR1 } & substrates & 5 chemotherapeutic drugs & $\begin{array}{l}\text { The three-dimensional crystal structure of Mus musculus } \\
\text { MDR1 (PDB ID: 4KSB) was used for modeling }\end{array}$ & Subhani et al. (2015) \\
\hline & inhibitors & 10 acetylated androstano-arylpyrimidines & $\begin{array}{l}\text { Homology model of the human MDR } 1 \text { was obtained from } \\
\text { the SWISS-MODEL. Molecular dockings were performed } \\
\text { with AutoDock }\end{array}$ & Gopisetty et al. (2021) \\
\hline & substrates & 3 compounds & $\begin{array}{l}\text { The Mdr1p 3D model based on the 3D model of MDR1-6 } \\
\text { (Expasy Q9URI1) }\end{array}$ & Redhu et al. (2016) \\
\hline & $\begin{array}{l}\text { substrates and } \\
\text { inhibitors }\end{array}$ & neochamaejasmin B & $\begin{array}{l}\text { The co-crystal of MDR1 (PDB entry: 3G5U) was obtained } \\
\text { from the RCSB Protein Data Bank }\end{array}$ & Eliaa et al. (2020) \\
\hline & inhibitors & 12 oxadiazolothiazin-3-one compounds & $\begin{array}{l}\text { The crystal structures of the MDR } 1 \text { from mouse. three- } \\
\text { dimensional model was built }\end{array}$ & Rosano et al. (2013) \\
\hline & $\begin{array}{l}\text { ligands or } \\
\text { inhibitors }\end{array}$ & 21 compounds & $\begin{array}{l}\text { P-glycoprotein were created using sequence homologies } \\
\text { between Sav186618 and the protein sequence of Pgp } \\
\text { (Uniprot entry P08183) }\end{array}$ & Wise (2012) \\
\hline & inhibitor & glabridin & $\begin{array}{l}\text { The initial structure of P-gp was obtained from the RCSB } \\
\text { protein data bank with ID of } 4 Q 9 \text { I }\end{array}$ & Qian et al. (2019) \\
\hline & $\begin{array}{l}\text { substrates and } \\
\text { inhibitors }\end{array}$ & $\begin{array}{l}1,1^{\prime}-\left(\left[1,1^{\prime} \text {-Biphenyl] }-4,4^{\prime} \text {-diyl)bis (3- }\right.\right. \\
\text { (piperidin-1-yl)propan-1-one)dihydrochloride }\end{array}$ & $\begin{array}{l}\text { Human MDR1 model was corrected using the Prepare } \\
\text { Protein tool of DS, and refined with CHARMm }\end{array}$ & Pang et al. (2017b) \\
\hline & inhibitors & 10 compounds from Heterotheca inuloides & $\begin{array}{l}\text { The dimensional structures of MDR1 (PDB: } 4 \mathrm{M} 1 \mathrm{M}) \text { was } \\
\text { used. The corrected mouse MDR1a (PDB ID: } 4 \mathrm{M} 1 \mathrm{M} \text { ) was } \\
\text { selected as the template protein }\end{array}$ & $\begin{array}{l}\text { Rodríguez-Chávez et al. } \\
\text { (2019) }\end{array}$ \\
\hline & substrates & 31 drugs & $\begin{array}{l}\text { MDR1 (PDB ID: } 4 \text { Q9H-L) docking model was built with } \\
\text { fifty side-chain variants }\end{array}$ & $\begin{array}{l}\text { Mukhametov and } \\
\text { Raevsky (2017) }\end{array}$ \\
\hline & inhibitors & $\begin{array}{l}22 \text { 1,2,3,4-Tetrahydroisoquinoline/2H- } \\
\text { chromen-2-one conjugates }\end{array}$ & $\begin{array}{l}\text { MDR1 homology model was optimized with } \\
\text { AUTODOCK 4.2.6 }\end{array}$ & Rullo et al. (2019) \\
\hline & inhibitors & 21 candidate drugs & $\begin{array}{l}\text { The structure of MDR1 was obtained from Protein Data } \\
\text { Bank (PDB 6QEX) }\end{array}$ & Beklen et al. (2020) \\
\hline & inhibitors & 87 natural flavonoids & $\begin{array}{l}\text { The three-dimensional structures of all the ligands were } \\
\text { prepared in Avogadro. the mouse MDR1 (PDB IDs: } 3 G 60 \\
\text { and } 4 \mathrm{M} 1 \mathrm{M} \text { ) and three available cryo-EM structures of the } \\
\text { human MDR1 (PDB IDs: 6COV, 6QEE, and 6QEX) were } \\
\text { used }\end{array}$ & Marques et al. (2021) \\
\hline & substrates & 2 flavonoids from Pistacia integerrima & $\begin{array}{l}\text { The 3-D structure of mice MDR1 was used from protein } \\
\text { data bank with } 4 Q 9 L\end{array}$ & Rauf et al. (2016) \\
\hline & inhibitors & 50 major herbal constituents & $\begin{array}{l}\text { The crystal structure of mouse MDR1 (PDB: 3G60) was } \\
\text { selected for molecular analysis }\end{array}$ & Li et al. (2014) \\
\hline & $\begin{array}{l}\text { substrates and } \\
\text { inhibitors }\end{array}$ & 51 chemicals & $\begin{array}{l}\text { A human MDR1 homology model was established based } \\
\text { on the mouse (Mus musculus) MDR1 protein (PDB ID: } \\
\text { 3G5U) }\end{array}$ & Li et al. (2021) \\
\hline & inhibitors & 75 flavonoids & $\begin{array}{l}\text { The crystal structure of mouse MDR1 (PDB: 3G60) was } \\
\text { used for docking }\end{array}$ & Bai et al. (2019) \\
\hline & inhibitors & 15 curcumin derivatives & $\begin{array}{l}\text { The X-ray crystal structure of murine MDR1 (PDB ID: } \\
4 \mathrm{M} 1 \mathrm{M} \text { ) and in complex with inhibitors QZ59Se-RRR } \\
\text { (PDB ID: 4M2S), QZ59Se-SSS (PDB ID: 4M2T) were } \\
\text { prepared for experiment }\end{array}$ & Sagnou et al. (2020) \\
\hline & inhibitors & 6 cardiotonic steroids & $\begin{array}{l}\text { Molecular docking was carried out on the crystal } \\
\text { structure of mouse P-glycoprotein (PDB code: } 3 G 60 \text { ) }\end{array}$ & Zeino et al. (2015) \\
\hline & inhibitors & $\begin{array}{l}3 \text { natural products and } 93,4- \\
\text { dihydroisocoumarins }\end{array}$ & $\begin{array}{l}\text { The cryo-EM structure of MDR1 (PDB ID: 6FN1) was } \\
\text { prepared for molecular docking }\end{array}$ & Sachs et al. (2019) \\
\hline
\end{tabular}


TABLE 6 | (Continued) Summary of published molecular docking models for assessing the substrates and inhibitors of drug transporters.

\begin{tabular}{|c|c|c|c|c|}
\hline Transporters & $\begin{array}{l}\text { Type of } \\
\text { compounds }\end{array}$ & $\begin{array}{l}\text { No. of compounds for } \\
\text { test }\end{array}$ & Descriptors & Reference \\
\hline & $\begin{array}{l}\text { substrates and } \\
\text { inhibitors }\end{array}$ & 11 Polyoxypregnanes & $\begin{array}{l}\text { X-ray structure of mouse P-glycoprotein (PDB ID: } 4 \mathrm{M} 1 \mathrm{M}) \\
\text { was used as template structure }\end{array}$ & To et al. (2017) \\
\hline & substrates & 7 dimeric sesquiterpene thioalkaloids & $\begin{array}{l}\text { Mouse P-glycoprotein (PDB ID: } 4 \text { M1M) was used for } \\
\text { analysis }\end{array}$ & Guragossian et al. (2021) \\
\hline & inhibitors & 4 sponge-derived sipholane triterpenoids & $\begin{array}{l}\text { MDR1 structure was prepared using Biopolymer-Prepare } \\
\text { protein structure-module within SYBYL 8.0. QZ59-RRR } \\
\text { binding site of MDR1 was analyzed }\end{array}$ & Abraham et al. (2010) \\
\hline \multirow[t]{13}{*}{ BCRP } & inhibitor & 11 flavonoids & $\begin{array}{l}\text { The cryo-EM structures of human BCRP (PDB mode: } \\
6 \text { FFC) was selected for experiment }\end{array}$ & Fan et al. (2019) \\
\hline & inhibitors & 10 compounds from Heterotheca inuloides & $\begin{array}{l}\text { The dimensional structures of BCRP (PDB ID: } 5 \mathrm{NJ} 3 \text { ) was } \\
\text { used }\end{array}$ & $\begin{array}{l}\text { Rodríguez-Chávez et al. } \\
\text { (2019) }\end{array}$ \\
\hline & $\begin{array}{l}\text { substrates and } \\
\text { inhibitors }\end{array}$ & 51 chemicals & $\begin{array}{l}\text { Three-dimensional crystal structure of BCRP (PDB ID: } \\
5 \mathrm{NJ} 3 \text { ) was used for docking }\end{array}$ & Li et al. (2021) \\
\hline & inhibitors & 11 natural compounds & $\begin{array}{l}\text { The target protein (PDB ID: } 6 E T I) \text { was performed for } \\
\text { molecular docking analysis }\end{array}$ & Banik et al. (2021) \\
\hline & inhibitors & 99 flavonoids & $\begin{array}{l}\text { The high resolutions cryo-EM structures of human BCRP } \\
\text { (PDB mode: } 6 F F C) \text { was selected for study }\end{array}$ & Fan et al. (2019) \\
\hline & substrates & 5 bisbenzylisoquinoline alkaloids & $\begin{array}{l}\text { BCRP model is based on the X-ray structure of mouse } \\
\text { P-glycoprotein (Protein Data Bank code 3G5U) }\end{array}$ & Tian et al. (2013) \\
\hline & substrates & 11 molecules & $\begin{array}{l}\text { The experiment was performed using the Glide docking } \\
\text { engine and the OPLS } 2005 \text { force field }\end{array}$ & Garg et al. (2015) \\
\hline & inhibitors & 68 compounds & $\begin{array}{l}\text { The cryo-EM structure of the ABCG2 transporter (PDB } \\
\text { ID: } 5 \mathrm{NJ} 3 \text { ) was used for experiment }\end{array}$ & Antoni et al. (2021) \\
\hline & inhibitors & 13 chromone-based molecules & $\begin{array}{l}\text { The two-fold symmetry axis of ABCG2 (PDB ID: 6FFC) } \\
\text { was used as a putative multidrug-binding site }\end{array}$ & Roussel et al. (2019) \\
\hline & inhibitors & 13 compounds & $\begin{array}{l}\text { The structure of the human ABCG2-MZ29eFab (PDB ID: } \\
6 \mathrm{HIJ}) \text { was taken for experiment }\end{array}$ & Roussel et al. (2020) \\
\hline & $\begin{array}{l}\text { substrates and } \\
\text { inhibitors }\end{array}$ & 22 compounds & $\begin{array}{l}\text { The human BCRP homology model developed in-house } \\
\text { were used as templates for molecular docking }\end{array}$ & Ferreira et al. (2018) \\
\hline & inhibitors & $\begin{array}{l}14 \text { Homo- and hetero-dimerization of indeno } \\
{[1,2-b] \text { indoles }}\end{array}$ & $\begin{array}{l}\text { The cryo-electron microscopy structure of ABCG2 (PDB } \\
\text { ID 5NJ3) was used to docking }\end{array}$ & Guragossian et al. (2021) \\
\hline & inhibitors & $\begin{array}{l}16 \text { differently } 6 \text {-substituted 4-anilino-2- } \\
\text { phenylpyrimidines } 16\end{array}$ & $\begin{array}{l}\text { MZ29 (PDB ID: 6FFC) was from Protein Data Bank (PDB) } \\
\text { was used for BCRP docking analysis }\end{array}$ & Silbermann et al. (2021) \\
\hline \multirow[t]{2}{*}{ MATE1 } & inhibitors & 881 compounds from the literature & $\begin{array}{l}\text { The FASTA sequence of human MATE1 was retrieved } \\
\text { from NCBI protein sequence database (Accession: } \\
\text { Q96FL8) and develop by four steps }\end{array}$ & Xu et al. (2015b) \\
\hline & inhibitor & 3 compounds & $\begin{array}{l}\text { The three-dimensional structure of hMATE1 was } \\
\text { predicted using Modeller, based on the NorM-VC (Protein } \\
\text { Data Bank ID: 3MKT) X-ray crystal structure data }\end{array}$ & Goda et al. (2021) \\
\hline hMATE2K & inhibitor & 3 compounds & $\begin{array}{l}\text { The three-dimensional structure of hMATE2K was } \\
\text { predicted using Modeller, based on the NorM-VC (Protein } \\
\text { Data Bank ID: 3MKT) X-ray crystal structure data }\end{array}$ & Goda et al. (2021) \\
\hline \multirow[t]{2}{*}{ MRP2 } & substrates & 11 polyphenolic compounds & $\begin{array}{l}\text { The Homology modeling of MRP2 were the structure of } \\
\text { Caenorhabditis elegans P-gp (PDB code: 4F4C) and the } \\
\text { human MRP1 (PDB code: } 2 \mathrm{CBZ} \text { ) }\end{array}$ & Fang et al. (2019b) \\
\hline & substrates & 44 compounds & $\begin{array}{l}\text { MRP2 was modelled on the template of bovine MRP1 } \\
\text { bound to leukotriene C4 (PDB ID: } 5 \text { UJA) }\end{array}$ & Deng et al. (2020a) \\
\hline \multirow[t]{4}{*}{ MRP4 } & $\begin{array}{l}\text { substrates and } \\
\text { inhibitors }\end{array}$ & $\begin{array}{l}10 \text { endogen substrates, } 12 \text { drug substrates, } \\
\text { and } 16 \text { drug inhibitors }\end{array}$ & $\begin{array}{l}\text { The structure of MRP4 was performed using its primary } \\
\text { sequence (code: O15439) from UniProt database }\end{array}$ & Becerra et al. (2021) \\
\hline & substrates & 4 model substrates & $\begin{array}{l}\text { The homology model of MRP4 was built based on the } \\
\text { Xray structure of P-glycoprotein (P-gp) from Mus } \\
\text { musculus (PDB ID: } 3 G 5 U \text { ) }\end{array}$ & Wittgen et al. (2012) \\
\hline & substrates & two mycophenolic acid-based compounds & $\begin{array}{l}\text { A 3D model of the human MRP4 protein in an inward } \\
\text { facing conformation was used for analysis }\end{array}$ & Berthier et al. (2021) \\
\hline & substrate & ginsenoside compound $\mathrm{K}$ & $\begin{array}{l}\text { Homology modeling of MRP4 was built by PSI-BLAST, } \\
\text { Clustal Omega and SAVES software }\end{array}$ & Zhou et al. (2019) \\
\hline
\end{tabular}

these transporters have been extensively studied in the hyperuricemia. Cephalexin is a substrate of OAT1 and is excreted via MATE1. Compared with that in control group, the $\mathrm{AUC}_{\text {inf }}$ of cephalexin was 2.66-fold and the $\mathrm{CL}_{\mathrm{R}}$ was 0.36 - fold in hyperuricemic rats, which were responsible for variations of drug transporters (Nishizawa et al., 2019). Clinically, it is suggested that, in the treatment of the hyperuricemia, it is necessary to pay special attentions to the dosage of the drugs 
that are primarily excreted by OAT1/3. Streptozotocin is the most commonly used agent to construct animal models of diabetes, due to its selective destruction of islet $\beta$ cells in animals (Goyal et al., 2016). In the diabetes model, the decreased OAT $1 / 3$ and OCT2 expressions and increased BCRP and MRP2/4 expressions were observed in the kidney (Xu et al., 2015a; Zhang et al., 2017b; Wang et al., 2018b). The excretion of antidiabetic drugs could be affected by these changed transporters. For example, metformin is excreted through OCT2, and sitagliptin is transported by OAT3 (Chu et al., 2007; Koepsell, 2013). Therefore, the clinical uses of these drugs during different disease statuses should take their pharmacokinetic changes into consideration. In general, most renal drug transporters are not affected by a long-term administration of a high-fat diet, but decreased expressions of the uptake protein OAT1/3 was observed in the kidney ( $\mathrm{Lu}$ et al., 2019), which can lead to an accumulation of endogenous toxic substances that may contribute to obesity-related diseases, such as hyperlipidemia, NAFLD, CKD, and diabetes.

\section{Effect of Other Diseases on Drug Transporters in Kidney}

Rheumatoid arthritis (RA) is an autoimmune disease mainly characterized by synovitis and with a prevalence of $0.24 \%$ in the world. This disease could decrease the protein level of OAT1, which may lead to an increased $t_{1 / 2}$ for some drugs (Wang et al., 2020a). In the high-altitude condition, the efflux drug transporters of MDR1 and MRP2 were increased, and clinicians should take it into consideration when drug prescription (Luo et al., 2017). It is noteworthy that different viral infections bring different changes of the renal transporter levels. The poly I:C infected pregnant rat showed lowered levels of OAT1/3, OATP4C1, BCRP, and MRP2 (Karimian Pour and Piquette-Miller, 2020), but the HIV-1 transgenic rat showed reduced OCT2 and MATE1 levels (Karimian Pour and Piquette-Miller, 2018). A hepatitis B virus infection could also damage kidneys, and it could downregulate some kidney transporters (Zuo et al., 2020). This difference should call attentions to pharmacokinetic performance shift of the used drug when different virus-infection in clinic. In an acute lymphoblastic leukemia mice model, the MRP 2/4 levels and the clearance of MRP-mediated drugs were significantly reduced, but the MDR1, OAT3, and OCT2 levels were increased, corresponding to the increased clearances of MDR1-mediated digoxin, OAT3mediated furosemide, and OCT2-mediated metformin (Zhou et al., 2020a). A study reported that female obese Zucker spontaneously hypertensive fatty rats showed a strongly decreased expression of OAT2 in the kidneys, and OAT2-mediated furosemide renal excretion could be impaired in these rats (Babelova et al., 2015). There may be other diseases affecting the levels of renal transporters and needing further explorations.

\section{MOLECULAR DOCKING METHOD OF DRUG-DRUG INTERACTIONS}

Currently, polypharmacy has become a common treatment in clinic. If two or more drugs are secreted simultaneously through the same drug transporters in the renal tubules, adverse drug events may increase due to DDIs. It has been reported that the incidence of DDIs can be as high as $8.34-100 \%$ of hospital admissions, which has attracted worldwide attention (de Oliveira et al., 2021). For instance, tenofovir, a representative substrate of OAT1, is a widely used antiviral drug. A clinical investigation showed that, when it was used with para-aminosalicylic acid (PAS, a long-standing antibiotic), the values of $\mathrm{C}_{\max }$ and $\mathrm{AUC}_{0-\mathrm{t}}$ of tenofovir were increased to approximately 3 -fold in the co-administration group than that in the alone group. In contrast, the cumulative amount of tenofovir in urine (Ae) was $20.87 \pm 5.60 \mathrm{mg}$ when alone use, and that is $7.45 \pm 2.56 \mathrm{mg}$ when it was co-administered with PAS (Parvez et al., 2021). Therefore, fast and accurate prediction of DDIs will effectively reduce unexpected clinical adverse events. Over the past decades, the FDA has issued a series of technical guidelines for DDI research, and the Center for Drug Evaluation of China has listed the common drugs as substrates and inhibitors (Sudsakorn et al., 2020; Center for Drug Evaluation and NMPA, 2021). Of note, in addition to in vivo and in vitro methods, an in silico approach has been officially promoted in the latest guidelines (Sudsakorn et al., 2020). Since it is not feasible to test all drugs for DDIs in vivo and/or in vitro, in silico modeling has become a useful tool to predict DDIs and help prescribing drugs.

Molecular docking is an in silico method based on the "lockand-key principle" that is used to find the best match between small molecule (ligand) and biological macromolecule (receptor) via electrostatic interaction, hydrophobic interaction, van der Waals force interaction, etc. (Pinzi and Rastelli, 2019). It consists of three interrelated parts: binding site recognition, conformational search algorithm, and scoring function. Binding site recognition refers to the identification of the active site in the target protein molecule that interacts with the ligand. Conformational search algorithm is to search the position, orientation, and conformation of ligand with some optimization algorithm only considering that ligand molecules are flexible. The scoring function is the evaluation of the combined conformation in the search (Kitchen et al., 2004). To date, molecular docking has been proven to be extremely useful in identifying substrate and/or inhibitor of drug transporters in a large group of compounds (Ai et al., 2015). A three-dimensional structure is a prerequisite for molecular docking. As shown in Figure 3, the homology models of OAT1, OAT3, OCT2, MDR1, BCRP, MATE1, MATE2-K, OAT4, MRP2, and MRP4 have been established (https://swissmodel. expasy.org/). Taking the MDR1 protein and its substrates and inhibitors as an example (Figure 4), the process of molecular docking is as follows: defining the binding site of the receptor protein, placing the small molecule at the binding site, and then searching for the optimal conformation of the interaction between the small molecule and the macromolecule by continuously optimizing the relative position, conformation, the side chain, and amino acid residues of the receptor. Ultimately, the scoring function is used to identify the ideal binding conformation with the highest score, in which the binding free energy of the receptor and ligand is the lowest and the affinity activity is the highest. Molecular docking provides a rapid method for a priori identification of 
potential transporter-mediated DDIs and/or drug-induced organ injury.

A large number of clinical events have demonstrated that the modulation of drug transporter activity could easily increase the potential risks of DDIs. Based on this notion, the FDA has explicitly stated that, when a drug under development is a transporter substrate and/or inhibitor, its interaction with a transporter should be evaluated (Sudsakorn et al., 2020). As shown in Table 6, a large number of compounds, especially natural products, have been assessed as drug transporter substrates and/ or inhibitors using molecular docking models. For instance, flavonoids are widely found in foods, such as fruits and vegetables. Bai et al. (2019) determined the inhibitory effects of 75 flavonoids on MDR1 protein, and confirmed that at least five flavonoids had significant inhibitory effect on MDR1, which was manifested in the increase of AUC and $\mathrm{C}_{\max }$ of digoxin when coadministration of digoxin and five flavonoids. Fan et al. (2019) have revealed the inhibitory effects of 99 flavonoids on BCRP, and found that 11 flavonoids had significant inhibitory effect on BCRP, which was manifested in the increase of $\mathrm{AUC}_{0-\mathrm{t}}$ of mitoxantrone when coadministration of mitoxantrone and these flavonoids. Chemical structure is the determining factor in binding the compound to the target protein, but it must be pointed out that many other factors, such as dose, genetics, and disease status, also play a role in the final biological effect of the compounds. In addition, the molecular docking was simulated independently by computer, and the potential involvement of other proteins from related pathways has not been considered. Therefore, although molecular docking provides a rapid screening method for the study of DDIs, it is essential for in vitro and in vivo experimental verification.

\section{CONCLUSION}

The systemic exposure of drug is influenced by complex systems, not just age, sex-gender, disease, and drug interactions, and renal drug transporter is one of the important factor determining the systemic exposure. The determinant roles of renal drug transporters have been identified in the renal excretion and disease progression. Their expressions in different species have direct impacts on drug disposal, which subsequently has the potential to influence the clinical efficacy of drugs from animals to the clinic in drug development. The expressions of transporters can vary up to 50-fold among species (e.g., BCRP). Interestingly, transporter expression significantly differs in different species and sexes. For instance, different MDR1 expression patterns were noted in rats and mice of different sexes. Therefore, it is very necessary to assess males and females in preclinical studies. Even in the same individual, the expressions of drug transporters could be decreased or increased under different pathological states. As mentioned, renal diseases, liver diseases, and systemic metabolic

\section{REFERENCES}

Abdussalam, A., Elshenawy, O. H., Bin Jardan, Y. A., El-Kadi, A. O. S., and Brocks, D. R. (2017). The Obesogenic Potency of Various High-Caloric Diet diseases could alter OAT1, OAT3, OCT2, MDR1, BCRP, MATE1, MATE2-K, MRP2, and MRP4 mRNA and/or protein levels. Therefore, we hypothesize that the expression levels of transporters can be used as an evaluation index for drug treatment effects. Unfortunately, changes in OATP4C1 and OAT4 in disease statuses have not been reported. Changes in transporter expression or the inhibition of transporter function will affect the pharmacokinetics of drugs in vivo, and reduce the therapeutic effect of drugs or increase the adverse reactions with the drug accumulation. Especially for drugs with strong toxicity or narrow therapeutic window, their side effects may even threaten the human life. Thus, the clinical dose of the transporter substrate may need to be adjusted when the level of the transporter changes. When the level of the transporter that promotes drug excretion is lowered, consideration should be given to reducing the dose or extending the duration of administration to avoid adverse reactions. Nevertheless, the adjustment of drug dose also depends on metabolic enzyme activity and other factors that affect the pharmacokinetic processes of drugs. With the wide application of drug combination, how to predict and avoid DDIs caused by drug transporters early has become an important challenge in drug administration. Traditional evaluation methods are mainly used in vivo animal models and in vitro renal cell line models. The in silico method provides an effective approach for rapidly screening of drug transporter substrates or inhibitors. In this paper, a large number of natural products were identified as substrates and/or inhibitors of transporters by molecular docking method. However, crystal structures of some drug transporters are still lacking, and the homology simulation method has inevitable disadvantages. Therefore, considerable work must be performed in the future to understand the structure-activity relationship of the interaction between transporters and drugs.

\section{AUTHOR CONTRIBUTIONS}

Conceptualization, ZC and ML; writing-original draft preparation, $\mathrm{WZ}$ and $\mathrm{BS}$; writing-review and editing, $\mathrm{WZ}$, $\mathrm{TZ}, \mathrm{ML}$, and $\mathrm{ZC}$; tables, $\mathrm{BS}$ and $\mathrm{YZ}$; figures, $\mathrm{BH}$ and $\mathrm{BO}$; supervision, ZC. All authors have read and agreed to the published version of the manuscript. All authors have read and agreed to the published version of the manuscript.

\section{FUNDING}

This research was funded by the Natural Science Foundation of Guangdong Province, Grant number 2021A1515011604 and Hunan Provincial Science and Technology Department, Grant numbers 2020RC3065, 2019SK1010, and 2019JJ30013.
Compositions in Male Rats, and Their Effects on Expression of Liver and Kidney Proteins Involved in Drug Elimination. J. Pharm. Sci. 106, 1650-1658. doi:10.1016/j.xphs.2017.02.002

Abraham, I., Jain, S., Wu, C. P., Khanfar, M. A., Kuang, Y., Dai, C. L., et al. (2010). Marine Sponge-Derived Sipholane Triterpenoids Reverse P-Glycoprotein 
(ABCB1)-Mediated Multidrug Resistance in Cancer Cells. Biochem. Pharmacol. 80, 1497-1506. doi:10.1016/j.bcp.2010.08.001

Ai, N., Fan, X., and Ekins, S. (2015). In Silico methods for Predicting Drug-Drug Interactions with Cytochrome P-450s, Transporters and beyond. Adv. Drug Deliv. Rev. 86, 46-60. doi:10.1016/j.addr.2015.03.006

Aleksunes, L. M., Augustine, L. M., Scheffer, G. L., Cherrington, N. J., and Manautou, J. E. (2008). Renal Xenobiotic Transporters Are Differentially Expressed in Mice Following Cisplatin Treatment. Toxicology 250, 82-88. doi:10.1016/j.tox.2008.06.009

Alghamdi, Y. S., Soliman, M. M., and Nassan, M. A. (2020). Impact of Lesinurad and Allopurinol on Experimental Hyperuricemia in Mice: Biochemical, Molecular and Immunohistochemical Study. BMC Pharmacol. Toxicol. 21, 10-0386. doi:10.1186/s40360-020-0386-7

Al-Majdoub, Z. M., Achour, B., Couto, N., Howard, M., Elmorsi, Y., Scotcher, D., et al. (2020). Mass Spectrometry-Based Abundance Atlas of ABC Transporters in Human Liver, Gut, Kidney, Brain and Skin. FEBS Lett. 594, 4134-4150. doi:10.1002/1873-3468.13982

Anderson, G. D. (2005). Sex and Racial Differences in Pharmacological Response: where Is the Evidence? Pharmacogenetics, Pharmacokinetics, and Pharmacodynamics. J. Womens Health (Larchmt) 14, 19-29. doi:10.1089/ jwh.2005.14.19

Andreollo, N. A., Santos, E. F., Araújo, M. R., and Lopes, L. R. (2012). Rat's Age versus Human's Age: what Is the Relationship? Arq. Bras. Cir. Dig. 25, 49-51. doi:10.1590/s0102-67202012000100011

Antoni, F., Wifling, D., and Bernhardt, G. (2021). Water-soluble Inhibitors of ABCG2 (BCRP) - A Fragment-Based and Computational Approach. Eur. J. Med. Chem. 210, 112958. doi:10.1016/j.ejmech.2020.112958

Babelova, A., Burckhardt, B. C., Wegner, W., Burckhardt, G., and Henjakovic, M. (2015). Sex-differences in Renal Expression of Selected Transporters and Transcription Factors in Lean and Obese Zucker Spontaneously Hypertensive Fatty Rats. J. Diabetes Res. 2015, 483238. doi:10.1155/2015/ 483238

Bai, J., Zhao, S., Fan, X., Chen, Y., Zou, X., Hu, M., et al. (2019). Inhibitory Effects of Flavonoids on P-Glycoprotein In Vitro and In Vivo: Food/herb-Drug Interactions and Structure-Activity Relationships. Toxicol. Appl. Pharmacol. 369, 49-59. doi:10.1016/j.taap.2019.02.010

Banik, A., Ghosh, K., Patil, U. K., and Gayen, S. (2021). Identification of Molecular Fingerprints of Natural Products for the Inhibition of Breast Cancer Resistance Protein (BCRP). Phytomedicine 85, 153523. doi:10.1016/j.phymed.2021.153523

Basit, A., Radi, Z., Vaidya, V. S., Karasu, M., and Prasad, B. (2019). Kidney Cortical Transporter Expression across Species Using Quantitative Proteomics. Drug Metab. Dispos. 47, 802-808. doi:10.1124/dmd.119.086579

Becerra, E., Aguilera-Durán, G., Berumen, L., Romo-Mancillas, A., and GarcíaAlcocer, G. (2021). Study of Endogen Substrates, Drug Substrates and Inhibitors Binding Conformations on MRP4 and its Variants by Molecular Docking and Molecular Dynamics. Molecules 26 (4), 1051. doi:10.3390/ molecules 26041051

Beklen, H., Gulfidan, G., Arga, K. Y., Mardinoglu, A., and Turanli, B. (2020). Drug Repositioning for P-Glycoprotein Mediated Co-Expression Networks in Colorectal Cancer. Front. Oncol. 10, 1273. doi:10.3389/fonc.2020.01273

Berthier, J., Benmameri, M., Sauvage, F. L., Fabre, G., Chantemargue, B., Arnion, H., et al. (2021). MRP4 Is Responsible for the Efflux Transport of Mycophenolic Acid $\beta$-d Glucuronide (MPAG) from Hepatocytes to Blood. Xenobiotica 51, 105-114. doi:10.1080/00498254.2020.1813352

Brandoni, A., and Torres, A. M. (2015). Altered Renal Expression of Relevant Clinical Drug Transporters in Different Models of Acute Uremia in Rats. Role of Urea Levels. Cell Physiol Biochem 36, 907-916. doi:10.1159/000430265

Brandoni, A., Villar, S. R., Picena, J. C., Anzai, N., Endou, H., and Torres, A. M. (2006). Expression of Rat Renal Cortical OAT1 and OAT3 in Response to Acute Biliary Obstruction. Hepatology 43, 1092-1100. doi:10.1002/hep.21142

Buist, S. C., and Klaassen, C. D. (2004). Rat and Mouse Differences in GenderPredominant Expression of Organic Anion Transporter (Oat1-3; Slc22a6-8) mRNA Levels. Drug Metab. Dispos. 32, 620-625. doi:10.1124/dmd.32.6.620

Canet, M. J., Hardwick, R. N., Lake, A. D., Dzierlenga, A. L., Clarke, J. D., Goedken, M. J., et al. (2015). Renal Xenobiotic Transporter Expression Is Altered in Multiple Experimental Models of Nonalcoholic Steatohepatitis. Drug Metab. Dispos. 43, 266-272. doi:10.1124/dmd.114.060574
Center for Drug Evaluation; NMPA (2021). Guidance on Drug Interaction Studies(for Trial Implementation). Available at: https://www.cde.org.cn/main/ news/viewInfoCommon/5a15b727e605482 c1cf594c689bb994b (Accessed January 21, 2021).

Chen, G., Tan, M. L., Li, K. K., Leung, P. C., and Ko, C. H. (2015). Green tea Polyphenols Decreases Uric Acid Level through Xanthine Oxidase and Renal Urate Transporters in Hyperuricemic Mice. J. Ethnopharmacol. 175, 14-20. doi:10.1016/j.jep.2015.08.043

Chen, Y. S., Chen, C. J., Yan, W., Ge, H. M., and Kong, L. D. (2017). Antihyperuricemic and Anti-inflammatory Actions of Vaticaffinol Isolated from Dipterocarpus Alatus in Hyperuricemic Mice. Chin. J. Nat. Med. 15, 330-340. doi:10.1016/S1875-5364(17)30053-5

Chen, X., Ge, H. Z., Lei, S. S., Jiang, Z. T., Su, J., He, X., et al. (2020). Dendrobium Officinalis Six Nostrum Ameliorates Urate Under-excretion and Protects Renal Dysfunction in Lipid Emulsion-Induced Hyperuricemic Rats. Biomed. Pharmacother. 132, 110765. doi:10.1016/j.biopha.2020.110765

Cheng, Q., Aleksunes, L. M., Manautou, J. E., Cherrington, N. J., Scheffer, G. L., Yamasaki, H., et al. (2008). Drug-metabolizing Enzyme and Transporter Expression in a Mouse Model of Diabetes and Obesity. Mol. Pharm. 5, 77-91. doi:10.1021/mp700114j

Chu, X. Y., Bleasby, K., Yabut, J., Cai, X., Chan, G. H., Hafey, M. J., et al. (2007). Transport of the Dipeptidyl Peptidase-4 Inhibitor Sitagliptin by Human Organic Anion Transporter 3, Organic Anion Transporting Polypeptide 4C1, and Multidrug Resistance P-Glycoprotein. J. Pharmacol. Exp. Ther. 321, 673-683. doi:10.1124/jpet.106.116517

Ciarimboli, G., Schröter, R., Neugebauer, U., Vollenbröker, B., Gabriëls, G., Brzica, H., et al. (2013). Kidney Transplantation Down-Regulates Expression of Organic Cation Transporters, Which Translocate $\beta$-blockers and Fluoroquinolones. Mol. Pharm. 10, 2370-2380. doi:10.1021/mp4000234

Clarke, J. D., Dzierlenga, A. L., Nelson, N. R., Li, H., Werts, S., Goedken, M. J., et al. (2015). Mechanism of Altered Metformin Distribution in Nonalcoholic Steatohepatitis. Diabetes 64, 3305-3313. doi:10.2337/db14-1947

de Oliveira, L. M., Diel, J. D. A. C., Nunes, A., and Da Silva Dal Pizzol, T. (2021). Prevalence of Drug Interactions in Hospitalised Elderly Patients: a Systematic Review. Eur. J. Hosp. Pharm. 28, 4-9. doi:10.1136/ejhpharm-2019-002111

Deng, F., Ghemtio, L., Grazhdankin, E., Wipf, P., Xhaard, H., and Kidron, H. (2020a). Binding Site Interactions of Modulators of Breast Cancer Resistance Protein, Multidrug Resistance-Associated Protein 2, and P-Glycoprotein Activity. Mol. Pharm. 17, 2398-2410. doi:10.1021/acs.molpharmaceut.0c00155

Deng, J. S., Jiang, W. P., Chen, C. C., Lee, L. Y., Li, P. Y., Huang, W. C., et al. (2020b). Cordyceps Cicadae Mycelia Ameliorate Cisplatin-Induced Acute Kidney Injury by Suppressing the TLR4/NF- $\mathrm{KB} / \mathrm{MAPK}$ and Activating the HO-1/Nrf2 and Sirt-1/AMPK Pathways in Mice. Oxid. Med. Cel Longev. 2020, 7912763. doi:10.1155/2020/7912763

Dong, Y., Gong, L., Lu, X., Ye, M., Lin, Y., Xie, S., et al. (2020). Changes of Transporters and Drug-Metabolizing Enzymes in Nephrotic Syndrome. Curr. Drug Metab. 21, 368-378. doi:10.2174/1389200221666200512113731

Ducatman, A., Luster, M., and Fletcher, T. (2021). Perfluoroalkyl Substance Excretion: Effects of Organic Anion-Inhibiting and Resin-Binding Drugs in a Community Setting. Environ. Toxicol. Pharmacol. 85, 103650. doi:10.1016/ j.etap. 2021.103650

Eliaa, S. G., Al-Karmalawy, A. A., Saleh, R. M., and Elshal, M. F. (2020). Empagliflozin and Doxorubicin Synergistically Inhibit the Survival of TripleNegative Breast Cancer Cells via Interfering with the mTOR Pathway and Inhibition of Calmodulin: In Vitro and Molecular Docking Studies. ACS Pharmacol. Transl Sci. 3, 1330-1338. doi:10.1021/acsptsci.0c00144

Fallon, J. K., Smith, P. C., Xia, C. Q., and Kim, M. S. (2016). Quantification of Four Efflux Drug Transporters in Liver and Kidney across Species Using Targeted Quantitative Proteomics by Isotope Dilution NanoLC-MS/MS. Pharm. Res. 33, 2280-2288. doi:10.1007/s11095-016-1966-5

Fan, X., Bai, J., Zhao, S., Hu, M., Sun, Y., Wang, B., et al. (2019). Evaluation of Inhibitory Effects of Flavonoids on Breast Cancer Resistance Protein (BCRP): From Library Screening to Biological Evaluation to Structure-Activity Relationship. Toxicol. Vitro 61, 104642. doi:10.1016/j.tiv.2019.104642

Fang, C., Chen, L., He, M., Luo, Y., Zhou, M., Zhang, N., et al. (2019a). Molecular Mechanistic Insight into the Anti-hyperuricemic Effect of Eucommia Ulmoides in Mice and Rats. Pharm. Biol. 57, 112-119. doi:10.1080/ 13880209.2019 .1568510 
Fang, Y., Cao, W., Liang, F., Xia, M., Pan, S., and Xu, X. (2019b). Structure Affinity Relationship and Docking Studies of Flavonoids as Substrates of MultidrugResistant Associated Protein 2 (MRP2) in MDCK/MRP2 Cells. Food Chem. 291, 101-109. doi:10.1016/j.foodchem.2019.03.111

Feng, Y., Sun, F., Gao, Y., Yang, J., Wu, G., Lin, S., et al. (2017). Taurine Decreased Uric Acid Levels in Hyperuricemic Rats and Alleviated Kidney Injury. Biochem. Biophys. Res. Commun. 489, 312-318. doi:10.1016/j.bbrc.2017.05.139

Ferreira, R. J., Baptista, R., Moreno, A., Madeira, P. G., Khonkarn, R., BaubichonCortay, H., et al. (2018). Optimizing the Flavanone Core toward New Selective Nitrogen-Containing Modulators of ABC Transporters. Future Med. Chem. 10, 725-741. doi:10.4155/fmc-2017-0228

Food and Drug Administration (2020). In Vitro Drug Interaction Studies - Cytochrome P450 Enzyme- and Transporter-Mediated Drug Interactions Guidance for Industry. Available at: https://www.fda.gov/media/134582/ download (Accessed May 7, 2020).

Freitas-Lima, L. C., Budu, A., Arruda, A. C., Perilhão, M. S., Barrera-Chimal, J., Araujo, R. C., et al. (2020). PPAR- $\alpha$ Deletion Attenuates Cisplatin Nephrotoxicity by Modulating Renal Organic Transporters MATE-1 and OCT-2. Int. J. Mol. Sci. 21 (19), 7416. doi:10.3390/ijms 21197416

Gai, Z., Visentin, M., Hiller, C., Krajnc, E., Li, T., Zhen, J., et al. (2016). Organic Cation Transporter 2 Overexpression May Confer an Increased Risk of Gentamicin-Induced Nephrotoxicity. Antimicrob. Agents Chemother. 60, 5573-5580. doi:10.1128/AAC.00907-16

Garg, P., Dhakne, R., and Belekar, V. (2015). Role of Breast Cancer Resistance Protein (BCRP) as Active Efflux Transporter on Blood-Brain Barrier (BBB) Permeability. Mol. Divers. 19, 163-172. doi:10.1007/s11030-014-9562-2

Gleeson, J. P., Fein, K. C., and Whitehead, K. A. (2021). Oral Delivery of Peptide Therapeutics in Infants: Challenges and Opportunities. Adv. Drug Deliv. Rev. 173, 112-124. doi:10.1016/j.addr.2021.03.011

Goda, M., Ikehara, M., Sakitani, M., Oda, K., Ishizawa, K., and Otsuka, M. (2021). Involvement of Human Multidrug and Toxic Compound Extrusion (MATE) Transporters in Testosterone Transport. Biol. Pharm. Bull. 44, 501-506. doi:10.1248/bpb.b20-00753

Gopisetty, M. K., Adamecz, D. I., Nagy, F. I., Baji, Á., Lathira, V., Szabó, M. R., et al. (2021). Androstano-arylpyrimidines: Novel Small Molecule Inhibitors of MDR1 for Sensitizing Multidrug-Resistant Breast Cancer Cells. Eur. J. Pharm. Sci. 156, 105587. doi:10.1016/j.ejps.2020.105587

Gottier Nwafor, J., Nowik, M., Anzai, N., Endou, H., and Wagner, C. A. (2020). Metabolic Acidosis Alters Expression of Slc22 Transporters in Mouse Kidney. Kidney Blood Press. Res. 45, 263-274. doi:10.1159/000506052

Goyal, S. N., Reddy, N. M., Patil, K. R., Nakhate, K. T., Ojha, S., Patil, C. R., et al. (2016). Challenges and Issues with Streptozotocin-Induced Diabetes - A Clinically Relevant Animal Model to Understand the Diabetes Pathogenesis and Evaluate Therapeutics. Chem. Biol. Interact. 244, 49-63. doi:10.1016/ j.cbi.2015.11.032

Gozalpour, E., and Fenner, K. S. (2018). Current State of In Vitro Cell-Based Renal Models. Curr. Drug Metab. 19, 310-326. doi:10.2174/ 1389200219666180119115133

Guragossian, N., Belhani, B., Moreno, A., Nunes, M. T., Gonzalez-Lobato, L., Marminon, C., et al. (2021). Uncompetitive Nanomolar Dimeric Indenoindole Inhibitors of the Human Breast Cancer Resistance Pump ABCG2. Eur. J. Med. Chem. 211, 113017. doi:10.1016/j.ejmech.2020.113017

Habu, Y., Yano, I., Takeuchi, A., Saito, H., Okuda, M., Fukatsu, A., et al. (2003). Decreased Activity of Basolateral Organic Ion Transports in Hyperuricemic Rat Kidney: Roles of Organic Ion Transporters, rOAT1, rOAT3 and rOCT2. Biochem. Pharmacol. 66, 1107-1114. doi:10.1016/ s0006-2952(03)00466-0

Hazelhoff, M. H., and Torres, A. M. (2021). Effect of Erythropoietin on MercuryInduced Nephrotoxicity: Role of Membrane Transporters. Hum. Exp. Toxicol. 40, 515-525. doi:10.1177/0960327120958109

Hull, R. P., and Goldsmith, D. J. (2008). Nephrotic Syndrome in Adults. BMJ 336, 1185-1189. doi:10.1136/bmj.39576.709711.80

Huls, M., Van Den Heuvel, J. J., Dijkman, H. B., Russel, F. G., and Masereeuw, R. (2006). ABC Transporter Expression Profiling after Ischemic Reperfusion Injury in Mouse Kidney. Kidney Int. 69, 2186-2193. doi:10.1038/sj.ki.5000407

Ivanyuk, A., Livio, F., Biollaz, J., and Buclin, T. (2017). Renal Drug Transporters and Drug Interactions. Clin. Pharmacokinet. 56, 825-892. doi:10.1007/s40262017-0506-8
Ji, L., Masuda, S., Saito, H., and Inui, K. (2002). Down-regulation of Rat Organic Cation Transporter rOCT2 by 5/6 Nephrectomy. Kidney Int. 62, 514-524. doi:10.1046/j.1523-1755.2002.00464.x

Ji, H. J., Li, J. Y., Wu, S. F., Wu, W. Y., Yao, C. L., Yao, S., et al. (2020). Two New Aristolochic Acid Analogues from the Roots of Aristolochia Contorta with Significant Cytotoxic Activity. Molecules 26 (1), 44 . doi:10.3390/ molecules 26010044

Jiang, Y., Quan, J., Chen, Y., Liao, X., Dai, Q., Lu, R., et al. (2019). Fluorofenidone Protects against Acute Kidney Injury. Faseb J. 33, 14325-14336. doi:10.1096/ fj.201901468RR

Joseph, S., Nicolson, T. J., Hammons, G., Word, B., Green-Knox, B., and LynCook, B. (2015). Expression of Drug Transporters in Human Kidney: Impact of Sex, Age, and Ethnicity. Biol. Sex. Differ. 6, 4-0020. doi:10.1186/s13293015-0020-3

Karimian Pour, N., and Piquette-Miller, M. (2018). Endotoxin Modulates the Expression of Renal Drug Transporters in HIV-1 Transgenic Rats. J. Pharm. Pharm. Sci. 21 (1s), 117s-129s. doi:10.18433/jpps30017

Karimian Pour, N., and Piquette-Miller, M. (2020). Dysregulation of Renal Transporters in a Rodent Model of Viral Infection. Int. Immunopharmacol. 80, 106135. doi:10.1016/j.intimp.2019.106135

Kim, H. S., Lim, S. W., Jin, L., Jin, J., Chung, B. H., and Yang, C. W. (2017). The Protective Effect of Febuxostat on Chronic Tacrolimus-Induced Nephrotoxicity in Rats. Nephron 135, 61-71. doi:10.1159/000449289

Kitchen, D. B., Decornez, H., Furr, J. R., and Bajorath, J. (2004). Docking and Scoring in Virtual Screening for Drug Discovery: Methods and Applications. Nat. Rev. Drug Discov. 3, 935-949. doi:10.1038/nrd1549

Koepsell, H. (2013). Polyspecific Organic Cation Transporters and Their Biomedical Relevance in Kidney. Curr. Opin. Nephrol. Hypertens. 22, 533-538. doi:10.1097/MNH.0b013e328363ffaf

Kong, F., Pang, X., Zhong, K., Guo, Z., Li, X., Zhong, D., et al. (2017). Increased Plasma Exposures of Conjugated Metabolites of Morinidazole in Renal Failure Patients: A Critical Role of Uremic Toxins. Drug Metab. Dispos. 45, 593-603. doi:10.1124/dmd.116.074492

Kusuhara, H., Ito, S., Kumagai, Y., Jiang, M., Shiroshita, T., Moriyama, Y., et al. (2011). Effects of a MATE Protein Inhibitor, Pyrimethamine, on the Renal Elimination of Metformin at Oral Microdose and at Therapeutic Dose in Healthy Subjects. Clin. Pharmacol. Ther. 89, 837-844. doi:10.1038/clpt.2011.36

Laouari, D., Yang, R., Veau, C., Blanke, I., and Friedlander, G. (2001). Two Apical Multidrug Transporters, P-Gp and MRP2, Are Differently Altered in Chronic Renal Failure. Am. J. Physiol. Ren. Physiol. 280 (4), F636-F645. doi:10.1152/ ajprenal.2001.280.4.F636

Le, Y., Zhou, X., Zheng, J., Yu, F., Tang, Y., Yang, Z., et al. (2020). AntiHyperuricemic Effects of Astaxanthin by Regulating Xanthine Oxidase, Adenosine Deaminase and Urate Transporters in Rats. Mar. Drugs 18, 610. doi:10.3390/md18120610

Li, X., Hu, J., Wang, B., Sheng, L., Liu, Z., Yang, S., et al. (2014). Inhibitory Effects of Herbal Constituents on P-Glycoprotein In Vitro and In Vivo: Herb-Drug Interactions Mediated via P-Gp. Toxicol. Appl. Pharmacol. 275, 163-175. doi:10.1016/j.taap.2013.12.015

Li, X., Yan, Z., Carlström, M., Tian, J., Zhang, X., Zhang, W., et al. (2020). Mangiferin Ameliorates Hyperuricemic Nephropathy Which Is Associated with Downregulation of AQP2 and Increased Urinary Uric Acid Excretion. Front. Pharmacol. 11, 49. doi:10.3389/fphar.2020.00049

Li, J., Sun, X., Xu, J., Tan, H., Zeng, E. Y., and Chen, D. (2021). Transplacental Transfer of Environmental Chemicals: Roles of Molecular Descriptors and Placental Transporters. Environ. Sci. Technol. 55, 519-528. doi:10.1021/ acs.est.0c06778

Lin, H., Tu, C., Niu, Y., Li, F., Yuan, L., Li, N., et al. (2019). Dual Actions of Norathyriol as a New Candidate Hypouricaemic Agent: Uricosuric Effects and Xanthine Oxidase Inhibition. Eur. J. Pharmacol. 853, 371-380. doi:10.1016/ j.ejphar.2019.04.034

Liu, T., Guo, X., Meng, Q., Wang, C., Liu, Q., Sun, H., et al. (2012). Effect of JBP485 on Obstructive Jaundice Is Related to Regulation of Renal Oat1, Oat3 and Mrp2 Expression in ANIT-Treated Rats. Peptides 36, 78-85. doi:10.1016/ j.peptides.2012.04.003

Liu, N., Wang, L., Yang, T., Xiong, C., Xu, L., Shi, Y., et al. (2015). EGF Receptor Inhibition Alleviates Hyperuricemic Nephropathy. J. Am. Soc. Nephrol. 26, 2716-2729. doi:10.1681/ASN.2014080793 
Liu, J., Lu, Y. F., Li, W. K., Zhou, Z. P., Li, Y. Y., Yang, X., et al. (2016). Mercury Sulfides Are Much Less Nephrotoxic Than Mercury Chloride and Methylmercury in Mice. Toxicol. Lett. 262, 153-160. doi:10.1016/ j.toxlet.2016.10.003

Liu, N., Xu, L., Shi, Y., Fang, L., Gu, H., Wang, H., et al. (2017). Pharmacologic Targeting ERK1/2 Attenuates the Development and Progression of Hyperuricemic Nephropathy in Rats. Oncotarget 8, 33807-33826. doi:10.18632/oncotarget.16995

Liu, Q., Liu, Z., Huo, X., Wang, C., Meng, Q., Sun, H., et al. (2018). Puerarin Improves Methotrexate-Induced Renal Damage by Up-Regulating Renal Expression of Oat1 and Oat3 In Vivo and In Vitro. Biomed. Pharmacother. 103, 915-922. doi:10.1016/j.biopha.2018.04.122

Ljubojević, M., Breljak, D., Herak-Kramberger, C. M., Anzai, N., and Sabolić, I. (2016). Expression of Basolateral Organic Anion and Cation Transporters in Experimental Cadmium Nephrotoxicity in Rat Kidney. Arch. Toxicol. 90, 525-541. doi:10.1007/s00204-015-1450-8

Lou, Y., Li, J., Lu, Y., Wang, X., Jiao, R., Wang, S., et al. (2011). Aristolochic AcidInduced Destruction of Organic Ion Transporters and Fatty Acid Metabolic Disorder in the Kidney of Rats. Toxicol. Lett. 201, 72-79. doi:10.1016/ j.toxlet.2010.12.007

Lu, X., Dong, Y., Jian, Z., Li, Q., Gong, L., Tang, L., et al. (2019). Systematic Investigation of the Effects of Long-Term Administration of a High-Fat Diet on Drug Transporters in the Mouse Liver, Kidney and Intestine. Curr. Drug Metab. 20, 742-755. doi:10.2174/1389200220666190902125435

Lu, S., Yang, X., Jiang, T., Zhou, H., Wang, W., Lin, N., et al. (2020). Pregnancy Impacts Entecavir Pharmacokinetics but Does Not Alter its Renal Excretion. J. Pharm. Sci. 109, 1811-1818. doi:10.1016/j.xphs.2020.01.027

Luo, B., Wang, R., Li, W., Yang, T., Wang, C., Lu, H., et al. (2017). Pharmacokinetic Changes of Norfloxacin Based on Expression of MRP2 after Acute Exposure to High Altitude at 4300m. Biomed. Pharmacother. 89, 1078-1085. doi:10.1016/ j.biopha.2017.02.092

Ma, Y. R., Qin, H. Y., Jin, Y. W., Huang, J., Han, M., Wang, X. D., et al. (2016). Gender-Related Differences in the Expression of Organic Cation Transporter 2 and its Role in Urinary Excretion of Metformin in Rats. Eur. J. Drug Metab. Pharmacokinet. 41, 559-565. doi:10.1007/s13318-015-0278-1

Ma, Y. R., Luo, X., Wu, Y. F., Zhang, T., Zhang, F., Zhang, G. Q., et al. (2018). Alteration of Renal Excretion Pathways in Gentamicin-Induced Renal Injury in Rats. J. Appl. Toxicol. 38, 968-977. doi:10.1002/jat.3603

Marques, M. B., De Oliveira, P. V., Fagan, S. B., Oliveira, B. R., Da Silva Nornberg, B. F., Almeida, D. V., et al. (2019). Modeling Drug-Drug Interactions of AZD1208 with Vincristine and Daunorubicin on Ligand-Extrusion Binding TMD-Domains of Multidrug Resistance P-Glycoprotein (ABCB1). Toxicology 411, 81-92. doi:10.1016/j.tox.2018.10.009

Marques, S. M., Šupolíková, L., Molčanová, L., Šmejkal, K., Bednar, D., and Slaninová, I. (2021). Screening of Natural Compounds as P-Glycoprotein Inhibitors against Multidrug Resistance. Biomedicines 9, 357. doi:10.3390/ biomedicines 9040357

Matsuzaki, T., Watanabe, H., Yoshitome, K., Morisaki, T., Hamada, A., Nonoguchi, H., et al. (2007). Downregulation of Organic Anion Transporters in Rat Kidney under Ischemia/reperfusion-Induced Acute [corrected] Renal Failure. Kidney Int. 71, 539-547. doi:10.1038/sj.ki.5002104

Matsuzaki, T., Morisaki, T., Sugimoto, W., Yokoo, K., Sato, D., Nonoguchi, H., et al. (2008). Altered Pharmacokinetics of Cationic Drugs Caused by DownRegulation of Renal Rat Organic Cation Transporter 2 (Slc22a2) and Rat Multidrug and Toxin Extrusion 1 (Slc47a1) in Ischemia/reperfusion-Induced Acute Kidney Injury. Drug Metab. Dispos. 36, 649-654. doi:10.1124/ dmd.107.019869

Mukhametov, A., and Raevsky, O. A. (2017). On the Mechanism of Substrate/nonSubstrate Recognition by P-Glycoprotein. J. Mol. Graph. Model. 71, 227-232. doi:10.1016/j.jmgm.2016.12.008

Nagura, M., Tamura, Y., Kumagai, T., Hosoyamada, M., and Uchida, S. (2016). Uric Acid Metabolism of Kidney and Intestine in a Rat Model of Chronic Kidney Disease. Nucleosides Nucleotides Nucleic Acids 35, 550-558. doi:10.1080/15257770.2016.1163379

Nakamura, K., Hirayama-Kurogi, M., Ito, S., Kuno, T., Yoneyama, T., Obuchi, W., et al. (2016). Large-scale Multiplex Absolute Protein Quantification of Drug-Metabolizing Enzymes and Transporters in Human Intestine, Liver, and Kidney Microsomes by SWATH-MS: Comparison with MRM/SRM and HR-MRM/PRM. Proteomics 16, 2106-2117. doi:10.1002/ pmic. 201500433

Nishizawa, K., Yoda, N., Morokado, F., Komori, H., Nakanishi, T., and Tamai, I. (2019). Changes of Drug Pharmacokinetics Mediated by Downregulation of Kidney Organic Cation Transporters Mate1 and Oct2 in a Rat Model of Hyperuricemia. PLoS ONE 14, e0214862. doi:10.1371/journal.pone.0214862

Niu, Y., Yang, P., Li, H., Li, Q., Lin, H., Gao, L., et al. (2020). Olsalazine Sodium Increases Renal Urate Excretion by Modulating Urate Transporters in Hyperuricemic Animals. Biol. Pharm. Bull. 43, 1653-1659. doi:10.1248/ bpb.b20-00362

Pang, M., Fang, Y., Chen, S., Zhu, X., Shan, C., Su, J., et al. (2017a). Gypenosides Inhibits Xanthine Oxidoreductase and Ameliorates Urate Excretion in Hyperuricemic Rats Induced by High Cholesterol and High Fat Food (Lipid Emulsion). Med. .Sci. Monit. 23, 1129-1140. doi:10.12659/ msm.903217

Pang, X., Wang, L., Kang, D., Zhao, Y., Wu, S., Liu, A. L., et al. (2017b). Effects of P-Glycoprotein on the Transport of DL0410, a Potential Multifunctional Antialzheimer Agent. Molecules 22 (8), 1246. doi:10.3390/molecules22081246

Parvez, M. M., Kalkisim, S., Nguyen, P. T. T., Jung, J. A., Park, J. K., Ghim, J. L., et al. (2021). Para-aminosalicylic Acid Significantly Reduced Tenofovir Exposure in Human Subjects: Mismatched Findings from In Vitro to In Vivo Translational Research. Br. J. Clin. Pharmacol. 25, 15056. doi:10.1111/bcp.15056

Perry, M. C., Hoagland, H. C., and Wagoner, R. D. (1976). Uric Acid Nephropathy. JAMA 236, 961-962. doi:10.1001/jama.236.8.961

Pinzi, L., and Rastelli, G. (2019). Molecular Docking: Shifting Paradigms in Drug Discovery. Int. J. Mol. Sci. 20 (18), 4331. doi:10.3390/ijms20184331

Qian, J., Xia, M., Liu, W., Li, L., Yang, J., Mei, Y., et al. (2019). Glabridin Resensitizes P-Glycoprotein-Overexpressing Multidrug-Resistant Cancer Cells to Conventional Chemotherapeutic Agents. Eur. J. Pharmacol. 852, 231-243. doi:10.1016/j.ejphar.2019.04.002

Raj, D., Tomar, B., Lahiri, A., and Mulay, S. R. (2020). The Gut-Liver-Kidney axis: Novel Regulator of Fatty Liver Associated Chronic Kidney Disease. Pharmacol. Re.s 152, 104617. doi:10.1016/j.phrs.2019.104617

Rauf, A., Uddin, G., Raza, M., Ahmad, B., Jehan, N., Siddiqui, B. S., et al. (2016). Reversal of Multidrug Resistance in Mouse Lymphoma Cells by Extracts and Flavonoids from Pistacia Integerrima. Asian Pac. J. Cancer Prev. 17, 51-55. doi:10.7314/apjcp.2016.17.1.51

Redhu, A. K., Khandelwal, N. K., Banerjee, A., Moreno, A., Falson, P., and Prasad, R. (2016). pHluorin Enables Insights into the Transport Mechanism of Antiporter Mdr1: R215 Is Critical for Drug/H+ Antiport. Biochem. J. 473, 3127-3145. doi:10.1042/BCJ20160407

Ren, J., Zhou, Y., Zhang, G., Zhou, L., Zhao, J., Wei, Y., et al. (2015). Role of AgeRelated Decrease of Renal Organic Cation Transporter 2 in the Effect of Atenolol on Renal Excretion of Metformin in Rats. Eur. J. Drug Metab. Pharmacokinet. 40, 349-354. doi:10.1007/s13318-014-0214-9

Rodríguez-Chávez, J. L., Méndez-Cuesta, C. A., Ramírez-Apan, T., Egas, V., Ávila, J. L., Neira-González, A., et al. (2019). Chemo-sensitizing Activity of Natural Cadinanes from Heterotheca Inuloides in Human Uterine Sarcoma Cells and Their In Silico Interaction with ABC Transporters. Bioorg. Chem. 91, 103091. doi:10.1016/j.bioorg.2019.103091

Rosano, C., Viale, M., Cosimelli, B., Severi, E., Gangemi, R., Ciogli, A., et al. (2013). ABCB1 Structural Models, Molecular Docking, and Synthesis of New Oxadiazolothiazin-3-One Inhibitors. ACS Med. Chem. Lett. 4, 694-698. doi: $10.1021 / \mathrm{ml} 300436 \mathrm{x}$

Roussel, E., Tran-Nguyen, V. K., Bouhedjar, K., Dems, M. A., Belaidi, A., Matougui, B., et al. (2019). Optimization of the Chromone Scaffold through QSAR and Docking Studies: Identification of Potent Inhibitors of ABCG2. Eur. J. Med. Chem. 184, 111772. doi:10.1016/j.ejmech.2019.111772

Roussel, E., Moréno, A., Altounian, N., Philouze, C., Pérès, B., Thomas, A., et al. (2020). Chromones Bearing Amino Acid Residues: Easily Accessible and Potent Inhibitors of the Breast Cancer Resistance Protein ABCG2. Eur. J. Med. Chem. 202, 112503. doi:10.1016/j.ejmech.2020.112503

Rukavina Mikusic, N. L., Kouyoumdzian, N. M., Uceda, A., Del Mauro, J. S., Pandolfo, M., Gironacci, M. M., et al. (2018). Losartan Prevents the Imbalance between Renal Dopaminergic and Renin Angiotensin Systems Induced by Fructose Overload. L-Dopa/dopamine index as New Potential Biomarker of Renal Dysfunction. Metabolism 85, 271-285. doi:10.1016/ j.metabol.2018.04.010 
Rullo, M., Niso, M., Pisani, L., Carrieri, A., Colabufo, N. A., Cellamare, S., et al. (2019). 1,2,3,4-Tetrahydroisoquinoline/2H-chromen-2-one Conjugates as Nanomolar P-Glycoprotein Inhibitors: Molecular Determinants for Affinity and Selectivity over Multidrug Resistance Associated Protein 1. Eur. J. Med. Chem. 161, 433-444. doi:10.1016/j.ejmech.2018.10.043

Sachs, J., Döhl, K., Weber, A., Bonus, M., Ehlers, F., Fleischer, E., et al. (2019). Novel 3,4-Dihydroisocoumarins Inhibit Human P-Gp and BCRP in Multidrug Resistant Tumors and Demonstrate Substrate Inhibition of Yeast Pdr5. Front. Pharmacol. 10, 400. doi:10.3389/fphar.2019.00400

Sagnou, M., Novikov, F. N., Ivanova, E. S., Alexiou, P., Stroylov, V. S., Titov, I. Y., et al. (2020). Novel Curcumin Derivatives as P-Glycoprotein Inhibitors: Molecular Modeling, Synthesis and Sensitization of Multidrug Resistant Cells to Doxorubicin. Eur. J. Med. Chem. 198, 112331. doi:10.1016/ j.ejmech.2020.112331

Schneider, R., Sauvant, C., Betz, B., Otremba, M., Fischer, D., Holzinger, H., et al. (2007). Downregulation of Organic Anion Transporters OAT1 and OAT3 Correlates with Impaired Secretion of Para-Aminohippurate after Ischemic Acute Renal Failure in Rats. Am. J. Physiol. Ren. Physiol. 292, F1599-F1605. doi:10.1152/ajprenal.00473.2006

Sengupta, P. (2013). The Laboratory Rat: Relating its Age with Human's. Int. J. Prev. Med. 4, 624-630.

Shiva, N., Sharma, N., Kulkarni, Y. A., Mulay, S. R., and Gaikwad, A. B. (2020). Renal Ischemia/reperfusion Injury: An Insight on In Vitro and In Vivo Models. Life Sci. 256, 117860. doi:10.1016/j.lfs.2020.117860

Silbermann, K., Li, J., Namasivayam, V., Stefan, S. M., and Wiese, M. (2021). Rational Drug Design of 6-substituted 4-Anilino-2-Phenylpyrimidines for Exploration of Novel ABCG2 Binding Site. Eur. J. Med. Chem. 212, 113045. doi:10.1016/j.ejmech.2020.113045

Simonetto, D. A., Gines, P., and Kamath, P. S. (2020). Hepatorenal Syndrome: Pathophysiology, Diagnosis, and Management. Bmj 370, m2687. doi:10.1136/ bmj.m2687

Slitt, A. L., Allen, K., Morrone, J., Aleksunes, L. M., Chen, C., Maher, J. M., et al. (2007). Regulation of Transporter Expression in Mouse Liver, Kidney, and Intestine during Extrahepatic Cholestasis. Biochim. Biophys. Acta 1768, 637-647. doi:10.1016/j.bbamem.2006.10.008

Soetikno, V., Sari, S. D. P., Ul Maknun, L., Sumbung, N. K., Rahmi, D. N. I., Pandhita, B. A. W., et al. (2019). Pre-Treatment with Curcumin Ameliorates Cisplatin-Induced Kidney Damage by Suppressing Kidney Inflammation and Apoptosis in Rats. Drug Res. (Stuttg) 69, 75-82. doi:10.1055/a-06415148

Song, I. H., Zong, J., Borland, J., Jerva, F., Wynne, B., Zamek-Gliszczynski, M. J., et al. (2016). The Effect of Dolutegravir on the Pharmacokinetics of Metformin in Healthy Subjects. J. Acquir. Immune. Defic. Syndr. 72, 400-407. doi:10.1097/ QAI.0000000000000983

Su, Q., Su, H., Nong, Z., Li, D., Wang, L., Chu, S., et al. (2018). Hypouricemic and Nephroprotective Effects of an Active Fraction from Polyrhachis Vicina Roger on Potassium Oxonate-Induced Hyperuricemia in Rats. Kidney Blood Press. Res. 43, 220-233. doi:10.1159/000487675

Subhani, S., Jayaraman, A., and Jamil, K. (2015). Homology Modelling and Molecular Docking of MDR1 with Chemotherapeutic Agents in Non-small Cell Lung Cancer. Biomed. Pharmacother. 71, 37-45. doi:10.1016/ j.biopha.2015.02.009

Sudsakorn, S., Bahadduri, P., Fretland, J., and Lu, C. (2020). 2020 FDA Drug-Drug Interaction Guidance: A Comparison Analysis and Action Plan by Pharmaceutical Industrial Scientists. Curr. Drug Metab. 21, 403-426. doi:10.2174/1389200221666200620210522

Tanaka, Y., Kobayashi, Y., Gabazza, E. C., Higuchi, K., Kamisako, T., Kuroda, M., et al. (2002). Increased Renal Expression of Bilirubin Glucuronide Transporters in a Rat Model of Obstructive Jaundice. Am. J. Physiol. Gastrointest. Liver Physiol. 282, G656-G662. doi:10.1152/ajpgi.00383.2001

Tanaka, Y., Chen, C., Maher, J. M., and Klaassen, C. D. (2008). Ischemiareperfusion of Rat Livers Decreases Liver and Increases Kidney Multidrug Resistance Associated Protein 2 (Mrp2). Toxicol. Sci. 101, 171-178. doi:10.1093/toxsci/ $/ \mathrm{km} 261$

Taniguchi, T., Omura, K., Motoki, K., Sakai, M., Chikamatsu, N., Ashizawa, N., et al. (2021). Hypouricemic Agents Reduce Indoxyl Sulfate Excretion by Inhibiting the Renal Transporters OAT1/3 and ABCG2. Sci. Rep. 11, 7232. doi:10.1038/s41598-021-86662-9
Targher, G., Bertolini, L., Rodella, S., Lippi, G., Zoppini, G., and Chonchol, M. (2010). Relationship between Kidney Function and Liver Histology in Subjects with Nonalcoholic Steatohepatitis. Clin. J. Am. Soc. Nephrol. 5, 2166-2171. doi:10.2215/CJN.05050610

Tian, Y., Qian, S., Jiang, Y., Shen, Q., Zheng, J., Zhou, H., et al. (2013). The Interaction between Human Breast Cancer Resistance Protein (BCRP) and Five Bisbenzylisoquinoline Alkaloids. Int. J. Pharm. 453, 371-379. doi:10.1016/ j.ijpharm.2013.05.053

To, K. K. W., Wu, X., Yin, C., Chai, S., Yao, S., Kadioglu, O., et al. (2017). Reversal of Multidrug Resistance by Marsdenia Tenacissima and its Main Active Ingredients Polyoxypregnanes. J. Ethnopharmacol. 203, 110-119. doi:10.1016/j.jep.2017.03.051

Toyoki, D., Shibata, S., Kuribayashi-Okuma, E., Xu, N., Ishizawa, K., Hosoyamada, M., et al. (2017). Insulin Stimulates Uric Acid Reabsorption via Regulating Urate Transporter 1 and ATP-Binding Cassette Subfamily G Member 2. Am. J. Physiol. Ren. Physiol. 313, F826-F834. doi:10.1152/ajprenal.00012.2017

Vinarov, Z., Abrahamsson, B., Artursson, P., Batchelor, H., Berben, P., BernkopSchnürch, A., et al. (2021). Current Challenges and Future Perspectives in Oral Absorption Research: An Opinion of the UNGAP Network. Adv. Drug Deliv. Rev. 171, 289-331. doi:10.1016/j.addr.2021.02.001

Wan, Z., Song, L., Hu, L., Lei, X., Huang, Y., and Lv, Y. (2021). Temporal Trends in Hyperuricaemia Among Adults in Wuhan City, China, from 2010 to 2019: a Cross-Sectional Study. BMJ Open 11, e043917. doi:10.1136/bmjopen-2020043917

Wang, R., Ma, C. H., Zhou, F., and Kong, L. D. (2016). Siwu Decoction Attenuates Oxonate-Induced Hyperuricemia and Kidney Inflammation in Mice. Chin. J. Nat. Med. 14, 499-507. doi:10.1016/S1875-5364(16)30059-0

Wang, H., Sun, P., Wang, C., Meng, Q., Liu, Z., Huo, X., et al. (2018a). Pharmacokinetic Changes of Cefdinir and Cefditoren and its Molecular Mechanisms in Acute Kidney Injury in Rats. J. Pharm. Pharmacol. 70, 1503-1512. doi:10.1111/jphp.12994

Wang, J., Zhai, T., and Chen, Y. (2018b). Effects of Honokiol on CYP450 Activity and Transporter mRNA Expression in Type 2 Diabetic Rats. Int. J. Mol. Sci. 19, 815. doi:10.3390/ijms 19030815

Wang, X., Han, L., Li, G., Peng, W., Gao, X., Klaassen, C. D., et al. (2018c). From the Cover: Identification of Natural Products as Inhibitors of Human Organic Anion Transporters (OAT1 and OAT3) and Their Protective Effect on Mercury-Induced Toxicity. Toxicol. Sci. 161, 321-334. doi:10.1093/toxsci/ $\mathrm{kfx} 216$

Wang, S., Fang, Y., Yu, X., Guo, L., Zhang, X., and Xia, D. (2019a). The FlavonoidRich Fraction from Rhizomes of Smilax Glabra Roxb. Ameliorates Renal Oxidative Stress and Inflammation in Uric Acid Nephropathy Rats through Promoting Uric Acid Excretion. Biomed. Pharmacother. 111, 162-168. doi:10.1016/j.biopha.2018.12.050

Wang, Y., Ren, J., Sun, Q., Zhang, Z., Lin, Y., Deng, S., et al. (2019b). Organic Anion Transporter 3 (OAT3)-Mediated Transport of Dicaffeoylquinic Acids and Prediction of Potential Drug-Drug Interaction. Eur. J. Pharm. Sci. 133, 95-103. doi:10.1016/j.ejps.2019.03.022

Wang, C., Wei, X., Wu, Y., Tang, H., Wang, B., Wang, Y., et al. (2020a). CP-25 Improves Nephropathy in Collagen-Induced Arthritis Rats by Inhibiting the Renal Inflammatory Response. Int. Immunopharmacol. 88, 106997. doi:10.1016/j.intimp.2020.106997

Wang, X., Deng, J., Xiong, C., Chen, H., Zhou, Q., Xia, Y., et al. (2020b). Treatment with a PPAR- $\gamma$ Agonist Protects against Hyperuricemic Nephropathy in a Rat Model. Drug Des. Devel. Ther. 14, 2221-2233. doi:10.2147/DDDT.S247091

Wen, J., Zeng, M., Shu, Y., Guo, D., Sun, Y., Guo, Z., et al. (2015). Aging Increases the Susceptibility of Cisplatin-Induced Nephrotoxicity. Age (Dordr) 37, 112. doi:10.1007/s11357-310.1007/s11357-015-9844-3

Wen, S., Wang, D., Yu, H., Liu, M., Chen, Q., Bao, R., et al. (2020). The TimeFeature of Uric Acid Excretion in Hyperuricemia Mice Induced by Potassium Oxonate and Adenine. Int. J. Mol. Sci. 21, 5178. doi:10.3390/ijms21155178

Wise, J. G. (2012). Catalytic Transitions in the Human MDR1 P-Glycoprotein Drug Binding Sites. Biochemistry 51, 5125-5141. doi:10.1021/bi300299z

Wittgen, H. G., Van Den Heuvel, J. J., Krieger, E., Schaftenaar, G., Russel, F. G., and Koenderink, J. B. (2012). Phenylalanine 368 of Multidrug ResistanceAssociated Protein 4 (MRP4/ABCC4) Plays a Crucial Role in Substratespecific Transport Activity. Biochem. Pharmacol. 84, 366-373. doi:10.1016/ j.bcp.2012.04.012 
Wu, H., Zhou, M., Lu, G., Yang, Z., Ji, H., and Hu, Q. (2017). Emodinol Ameliorates Urate Nephropathy by Regulating Renal Organic Ion Transporters and Inhibiting Immune Inflammatory Responses in Rats. Biomed. Pharmacother. 96, 727-735. doi:10.1016/j.biopha.2017.10.051

Wu, Y., Wang, Y., Ou, J., Wan, Q., Shi, L., Li, Y., et al. (2018). Effect and Mechanism of ShiZhiFang on Uric Acid Metabolism in Hyperuricemic Rats. Evid. Based Complement. Alternat. Med. 2018, 6821387. doi:10.1155/2018/6821387

Xu, C., Zhu, L., Chan, T., Lu, X., Shen, W., Gillies, M. C., et al. (2015a). The Altered Renal and Hepatic Expression of Solute Carrier Transporters (SLCs) in Type 1 Diabetic Mice. PLoS ONE 10, e0120760. doi:10.1371/journal.pone.0120760

Xu, Y., Liu, X., Wang, Y., Zhou, N., Peng, J., Gong, L., et al. (2015b). Combinatorial Pharmacophore Modeling of Multidrug and Toxin Extrusion Transporter 1 Inhibitors: a Theoretical Perspective for Understanding Multiple Inhibitory Mechanisms. Sci. Rep. 5, 13684. doi:10.1038/srep13684

Xu, Y. J., Wang, Y., Lu, Y. F., Xu, S. F., Wu, Q., and Liu, J. (2017). Age-associated Differences in Transporter Gene Expression in Kidneys of Male Rats. Mol. Med. Rep. 15, 474-482. doi:10.3892/mmr.2016.5970

Yan, M., An, Y. T., Li, J., Wu, Z. Z., and Wang, T. (2014). Regulatory Effect of Leonurus Extracts on Hyperuricemia in Rats. Zhongguo Zhong Yao Za Zhi 39, 4856-4859.

Yang, X., and Han, L. (2019). Roles of Renal Drug Transporter in Drug Disposition and Renal Toxicity. Adv. Exp. Med. Biol. 1141, 341-360. doi:10.1007/978-98113-7647-4_7

Yang, Y., Zhang, D. M., Liu, J. H., Hu, L. S., Xue, Q. C., Ding, X. Q., et al. (2015). Wuling San Protects Kidney Dysfunction by Inhibiting Renal TLR4/MyD88 Signaling and NLRP3 Inflammasome Activation in High Fructose-Induced Hyperuricemic Mice. J. Ethnopharmacol. 169, 49-59. doi:10.1016/ j.jep.2015.04.011

Younossi, Z. M., Koenig, A. B., Abdelatif, D., Fazel, Y., Henry, L., and Wymer, M. (2016). Global Epidemiology of Nonalcoholic Fatty Liver Disease-MetaAnalytic Assessment of Prevalence, Incidence, and Outcomes. Hepatology 64, 73-84. doi:10.1002/hep.28431

Zeino, M., Paulsen, M. S., Zehl, M., Urban, E., Kopp, B., and Efferth, T. (2015). Identification of New P-Glycoprotein Inhibitors Derived from Cardiotonic Steroids. Biochem. Pharmacol. 93, 11-24. doi:10.1016/j.bcp.2014.10.009

Zhang, X., Shirahatti, N. V., Mahadevan, D., and Wright, S. H. (2005). A Conserved Glutamate Residue in Transmembrane helix 10 Influences Substrate Specificity of Rabbit OCT2 (SLC22A2). J. Biol. Chem. 280, 34813-34822. doi:10.1074/ jbc.M506342200

Zhang, W., Zhang, Q., Zheng, T. T., Zhen, J. C., and Niu, X. H. (2016). Delayed High-Dose Methotrexate Excretion and Influencing Factors in Osteosarcoma Patients. Chin. Med. J. (Engl) 129, 2530-2534. doi:10.4103/0366-6999.192781

Zhang, B. B., Li, W. K., Hou, W. Y., Luo, Y., Shi, J. Z., Li, C., et al. (2017a). Zuotai and $\mathrm{HgS}$ Differ from $\mathrm{HgCl} 2$ and Methyl Mercury in $\mathrm{Hg}$ Accumulation and Toxicity in Weanling and Aged Rats. Toxicol. Appl. Pharmacol. 331, 76-84. doi:10.1016/j.taap.2017.05.021

Zhang, H., Xie, H., Zheng, X., Chai, Y., Tang, Z., Chen, H., et al. (2017b). Salicylic Acid Retention Impairs Aspirin Reactivity in Type 2 Diabetes. Eur. J. Pharmacol. 794, 234-245. doi:10.1016/j.ejphar.2016.11.042
Zhang, R., Zhan, S., Li, S., Zhu, Z., He, J., Lorenzo, J. M., et al. (2018). Antihyperuricemic and Nephroprotective Effects of Extracts from Chaenomeles Sinensis (Thouin) Koehne in Hyperuricemic Mice. Food Funct. 9, 5778-5790. doi:10.1039/c8fo01480a

Zhang, K. H., Wang, M. Q., Wei, L. L., Feng, C. J., Zhang, Y. S., and Teng, J. B. (2020). Investigation of the Effects and Mechanisms of Dendrobium Loddigesii Rolfe Extract on the Treatment of Gout. Evid. Based Complement. Alterna.t Med. 2020, 4367347. doi:10.1155/2020/4367347

Zhao, X., Wang, J., Tang, L., Li, P., Ru, J., and Bai, Y. (2021). Withaferin A Protects against Hyperuricemia Induced Kidney Injury and its Possible Mechanisms. Bioengineered 12, 589-600. doi:10.1080/21655979.2021.1882761

Zhong, K., Li, X., Xie, C., Zhang, Y., Zhong, D., and Chen, X. (2014). Effects of Renal Impairment on the Pharmacokinetics of Morinidazole: Uptake Transporter-Mediated Renal Clearance of the Conjugated Metabolites. Antimicrob. Agents Chemother. 58, 4153-4161. doi:10.1128/AAC.02414-14

Zhou, L., Chen, L., Wang, Y., Huang, J., Yang, G., Tan, Z., et al. (2019). Impact of NR1I2, Adenosine Triphosphate-Binding Cassette Transporters Genetic Polymorphisms on the Pharmacokinetics of Ginsenoside Compound $\mathrm{K}$ in Healthy Chinese Volunteers. J. Ginseng Res. 43, 460-474. doi:10.1016/ j.jgr.2018.04.003

Zhou, Y., Du, B., Kan, M., Chen, S., Tang, B. H., Nie, A. Q., et al. (2020a). Drug Elimination Alteration in Acute Lymphoblastic Leukemia Mediated by Renal Transporters and Glomerular Filtration. Pharm. Res. 37, 158-02896. doi:10.1007/s11095-020-02896-8

Zhou, Z., Deng, L., Hu, L., Ren, Q., Zhang, L., and Li, Z. (2020b). Recent Advances in Research of Targets and Drugs for Treatment of Non-alcoholic Fatty Liver Disease. Chin. J. New Drugs 29, 1363-1374.

Zuo, T., Chen, P., Jing, S., Zhang, T., Chang, L., Xu, F., et al. (2020). Quantitative Proteomics Reveals the Development of HBV-Associated Glomerulonephritis Triggered by the Downregulation of SLC7A7. J. Proteome Res. 19, 1556-1564. doi:10.1021/acs.jproteome.9b00799

Conflict of Interest: The authors declare that the research was conducted in the absence of any commercial or financial relationships that could be construed as a potential conflict of interest.

Publisher's Note: All claims expressed in this article are solely those of the authors and do not necessarily represent those of their affiliated organizations, or those of the publisher, the editors, and the reviewers. Any product that may be evaluated in this article, or claim that may be made by its manufacturer, is not guaranteed or endorsed by the publisher.

Copyright (C) 2021 Zou, Shi, Zeng, Zhang, Huang, Ouyang, Cai and Liu. This is an open-access article distributed under the terms of the Creative Commons Attribution License (CC BY). The use, distribution or reproduction in other forums is permitted, provided the original author(s) and the copyright owner(s) are credited and that the original publication in this journal is cited, in accordance with accepted academic practice. No use, distribution or reproduction is permitted which does not comply with these terms. 